\title{
SEDIMENTOLOGY AND DIAGENESIS OF THE DINANTIAN SUCCESSION IN THE VINALMONT BOREHOLE
}

\author{
Peter NIELSEN ${ }^{1}$, Vera FLIPKENS ${ }^{1}$, Eric GROESSENS² \& Rudy SWENNEN ${ }^{1}$
}

(6 figures, 4 tables \& 2 plates)

1. Fysico-chemische Geologie, K.U.Leuven, Celestijnenlaan 200C, B-3001 Heverlee, Belgium

2. Geological Survey of Belgium, rue Jenner 13, B-1000 Brussels, Belgium

\begin{abstract}
The dolomites of the Grande Dolomie de Namur which make up the lower part of the Vinalmont borehole are considered to be eogenetic, i.e. relating to reflux of saline to hypersaline water or due to seawater circulation adjacent to the development of a mixing zone. Their depleted $\delta^{18} \mathrm{O}(-13.50 \%$ to $-13.90 \%)$ is interpreted in terms of recrystallisation due to interaction with high temperature fluids. Their $\delta^{13} \mathrm{C}$-composition $(-1.68 \%$ to $+1.50 \%$ o $\mathrm{PDB})$ roughly falls within the interval of the original Lower Carboniferous marine calcite, and thus has not been reset. Columnar calcites, which fill up many of the cavities within the upper part of the former formation, are interpreted as palaeo-speleothems of Upper Tournaisian/Lower Visean age. These dominantly non-luminescent columnar calcites with growth bands and microsparite intercalations of detrital origin display stable isotopic signatures supporting their meteoric origin $\left(\delta^{18} \mathrm{O}\right.$ - and $\delta^{13} \mathrm{C}$-values of $-6.49 \%$ to $-10.32 \%$ PDB and $-2.47 \%$ to $-4.79 \%$ PDB respectively). In the Vinalmont borehole the 'Encrinite de Flémalle' and the 'Limestone of Avins' are missing. This is explained by nondeposition or by erosion in relation to the just cited karstification. Within the overlying Terwagne Formation mud- to wackestones and peloidal pack- to grainstones display many features indicative of restricted sedimentation conditions with episodic emergence as testified by the development of palaeosols and subaerial crusts. The stable isotope values of these horizons support soil-related processes $\left(\delta^{18} \mathrm{O}\right.$ between $-8.55 \%$ and $-6.55 \%$ PDB and $\delta^{13} \mathrm{C}$ between $-5.95 \% \circ$ and $-1.03 \%$ PDB). An evolution towards more open marine subtidal sedimentation conditions in the Vinalmont Limestones (dominantly pack- to grainstones) is apparent based on the varied fauna assemblage and sedimentary characteristics. The original marine stable oxygen signature has also been reset due to interaction with meteoric water $(-9.45 \%$ o and $-9.70 \%$ PDB $)$ but their $\delta^{13} \mathrm{C}(+0.27 \%$ to $+1.07 \%$ PDB $)$ reflect a clear rock buffering with preservation of the original marine Lower Carboniferous signal.

The study of late diagenetic features is helped by the development of bed-parallel compactional and steeply inclined tectonic stylolites. Late diagenetic zebra-dolomite formation has been observed in the Grande Dolomie de Namur. They formed out of hot (mean $\mathrm{T}_{\mathrm{h}}$ of $115^{\circ} \mathrm{C} ; \delta^{18} \mathrm{O}$ of $-9.1 \%$ to $-9.4 \%$ PDB) suprahydrostatic fluids circulating along steep faults. The slightly depleted $\delta^{13} \mathrm{C}$-signal (varying between $-2.08 \%$ and $-3.09 \%$ PDB) might also reflect high temperature precipitation conditions. The development of mono-crystalline non-luminescent columnar calcites in these dolomites, filling up large cavities is a second important late diagenetic process. They are interpreted to be the product of hydrothermal karstification $\left(\delta^{18} \mathrm{O}\right.$-values of $-16.2 \%$ to $-16.7 \%$ PDB and $\delta^{13} \mathrm{C}$-values of $+0.07 \%$ to $-1.17 \%$ o PDB). Furthermore several fracturation events followed by cementation have been recognised of which the later generations typically are characterised by bright yellow luminescent calcite. They are thought to relate to thermal sulphate reduction and thus could be time equivalent with the late diagenetic pyrite which preferentially crystallised along the stylolites.
\end{abstract}

KEYWORDS: Lower Carboniferous, carbonate, sedimentology, diagenesis, stable isotopes, Belgium

\section{Introduction}

The Dinantian carbonate succession in southern Belgium has been intensively studied from a biostratigraphical, sedimentological and diagenetical point of view over the last tens of years. A large number of papers addresses especially the contact zone between dolomites and overlying limestones (e.g. Hance et al., this volume), which is either characterised by an important karst contact (as is the case in the Namur syncline; Damiaen, 1956) or by the presence of a intraformational breccia (Swennen et al., 1990). The latter is especially well developed in the Verviers synclinorium and the eastern part of the Dinant synclinorium. Also a lot of attention is paid to the circulation of fluids next to the Midi-Eifel overthrust (Muchez et al., 1995; 2000) since these fluids may provide infor- 


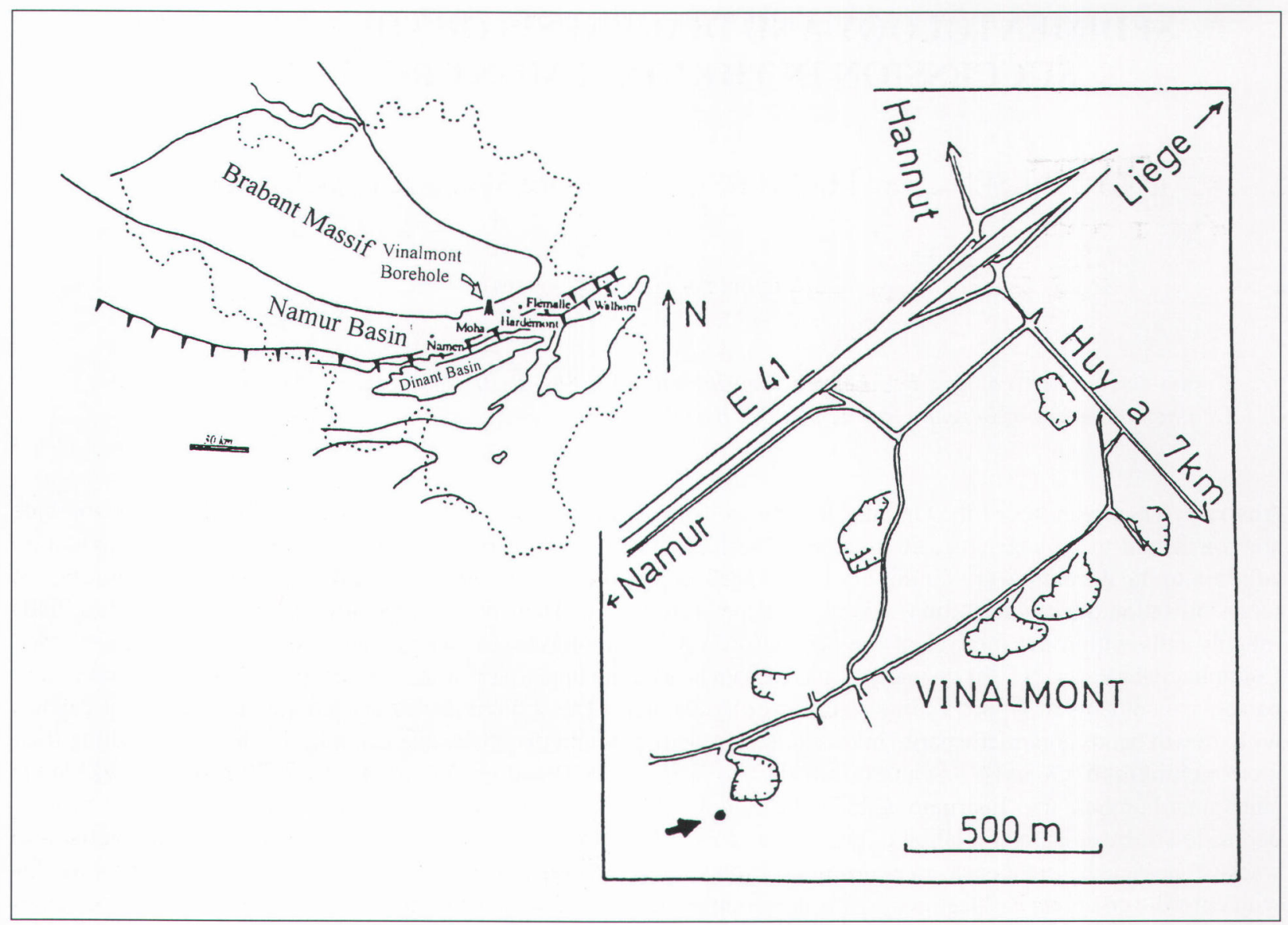

Figure 1. Geographical situation of the study area with indication of theVinalmont borehole

mation on the existence of economic deposits in the northern part of the Paleozoic succession in Southern Belgium. The aim of the present study is to address the early as well as the late diagenetic processes which affects the Dinantian limestones in the Moha area. In this study especially results from the boreholes placed near the city of Vinalmont are presented since the core material was of excellent quality and allowed studying in detail the relationships between different diagenetic products.

\section{Geological setting}

The borehole of Vinalmont was drilled $2.5 \mathrm{~km}$ east of Moha (Province de Namur: Fig. 1). It reached a depth of $130.3 \mathrm{~m}$ and cuts through a Lower Carboniferous sequence. From bottom to top it is possible to differentiate the top of the 'Grande Dolomie de Namur' Formation in which several columnar calcite horizons occur, the 'Terwagne Limestone', the 'Vinalmont Limestone' and the 'Lives Limestone' (Fig. 2).

The 'Grande Dolomie de Namur' can be subdivided in three zones based on the lithological characteristics. A first zone $(115.25 \mathrm{~m}-130.3 \mathrm{~m})$ is composed of a crinoidrich dolomite with decimeter-thick zebra dolomite intervals, and intercalations of limestone and rarely sandy lay- ers. The second zone (111.4m-115.25m) contains dolomite and recrystallised limestone. The last zone $(89.0 \mathrm{~m}-$ $111.4 \mathrm{~m}$ ) consists dominantly of limestone with intercalated cm-thick dolomite beds. The columnar calcites form a very particular lithology. They are present in all of the three zones and its vertical distribution is at least $40 \mathrm{~m}$. They mainly occur in karst cavities as can be deduced especially from neighboring outcrops. The exact contact between the 'Grande Dolomie de Namur' and the 'Terwagne Limestone' is not very clear. The contact is placed at an orange-brown sandy clay layer near $89.0 \mathrm{~m}$ depth by Hance and Groessens (1990) based on the disappearance of "brecciated" lithologies, which are common in the sequence below this sandy clay layer.

The 'Encrinite de Flémalle' and the 'Avins Limestone' Formations have not been recognised in this borehole. Most likely they were not deposited or became eroded soon after deposition. This can be explained by the very northern palaeo-position of this borehole with regard to the southern border of the Caledonian Brabant Massif, which acted as a paleohigh (Hance and Groessens, 1990). The 'Terwagne Limestone' (89.0m-65.5m) has a thickness of $23.5 \mathrm{~m}$ and is marked by the presence of two subaerial crusts and one well-developed palaeosol. This formation consists of micritic limestones with dolomite 


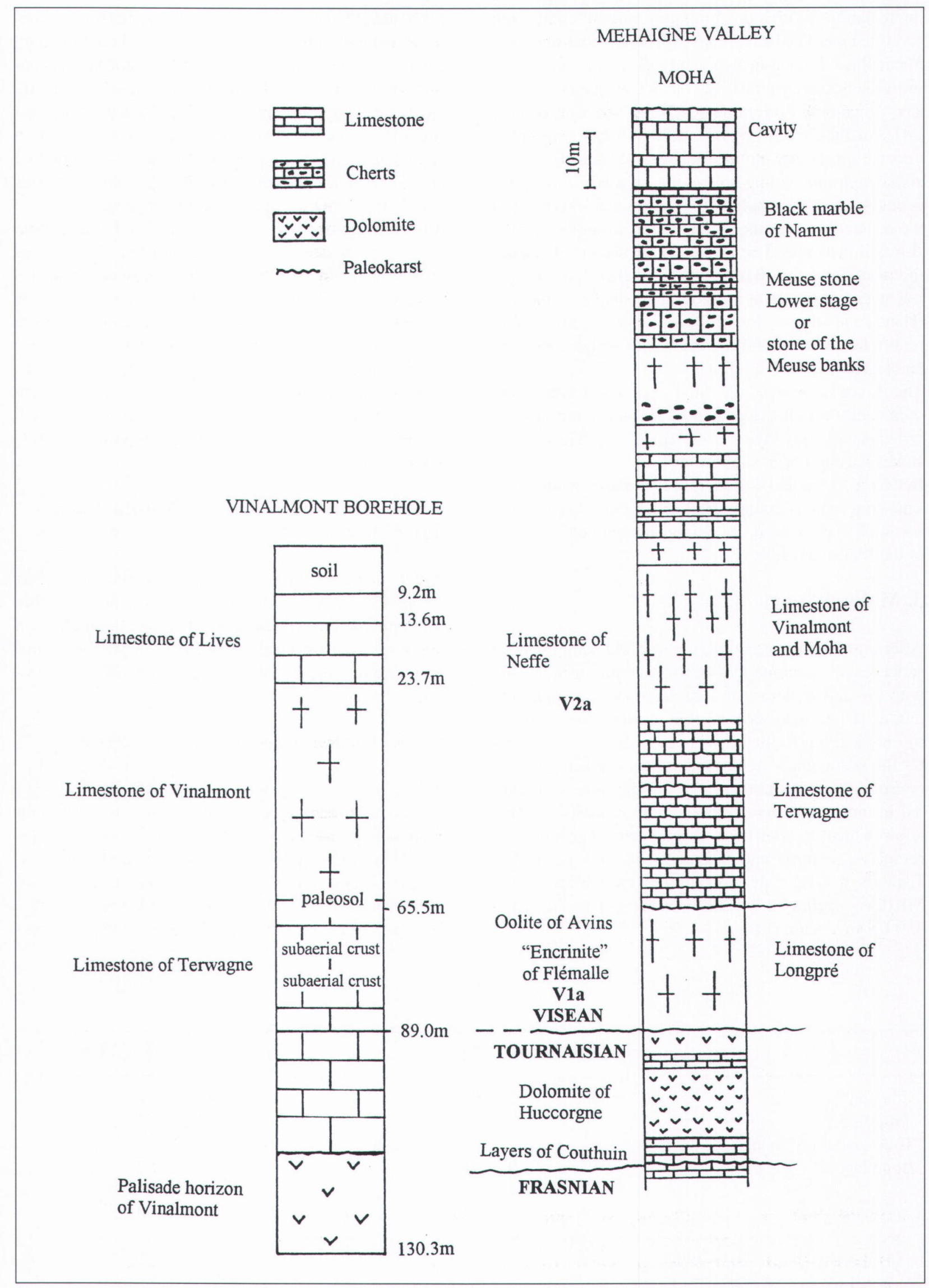

Figure 2. Stratigraphical log of the Vinalmont borehole with comparison of the stratigraphy of the Méhaigne Valley section according to Groessens (1985) 
intercalations. Within this formation several fracture and stylolite types can be recognised. The top is formed by a $50 \mathrm{~cm}$ thick orange-brown sandy clay-horizon, which most likely corresponds to a volcanic ash layer.

The 'Vinalmont Limestone' $(65.50 \mathrm{~m}-23.7 \mathrm{~m})$ consists of a $41.8 \mathrm{~m}$ thick deposit characterised by a light gray color, a coarse appearance, limited fractures and numerous horizontal stylolites. Some orange-brown sandy clay layers occur within this lithology. A similar clay layer forms the contact between the 'Vinalmont Limestone' and the 'Lives Limestone'. This clay layer is interpreted to mark the position of the 'Banc d'Or de Bachant', a volcanic ash layer that is used as a stratigraphic marker in the area (Hance and Groessens, 1990). According to the drilling report, however, this layer corresponds with a clay filled karst cavity.

The 'Lives Limestone' (23.7m-13.6m) has a darker gray dominantly micritic appearance. Stylolites and orangebrown sandy clay layers occur frequently. These limestones have not been studied.

Between $13.6 \mathrm{~m}$ and $4.4 \mathrm{~m}$ a rubble horizon, made up of limestone clasts, occurs. The uppermost $4.4 \mathrm{~m}$ of the borehole is composed of components derived from one of the Meuse terraces.

\section{Methodology}

After cutting and polishing, the selected samples were stained with Alizarine red-S and potassium ferricyanide with the aim to detect Fe-rich carbonate and dolomite phases (Dickson, 1966). 85 thin-sections were studied by classical transmitted light-microscopy in order to infer the sedimentary environment and to investigate the type of diagenetic carbonate phases. The latter were studied in more detail by cathodoluminescence (CL). This allowed identification of successive cement generations, replacive textures and fractures. For this purpose a Technosyn Cold Cathodo-Luminescence Model 8200 MKII was operated at $16-20 \mathrm{kV}$ accelerating potential and 450-650mA beam current. $\delta^{18} \mathrm{O}$ - and $\delta^{13} \mathrm{C}$-isotope analyses were carried out on limestone and dolomite host rock samples and on individual diagenetic phases, i.e. calcites and dolomites (data results in Annex 1a-b). To interpret the results correctly the stable isotopic composition of marine calcite precipitates of Carboniferous age must be taken into account. In table 1 a summary of published results for Dinantian marine carbonates according to Bruckschen and Veizer (1997) and Bruckschen et al. (1999) is given.

Isotope analyses were carried out with a Finnigan Mat delta E stable isotope mass spectrometer. The samples were treated with $\geq 100 \%$ orthophosphoric acid at a temperature of $25^{\circ} \mathrm{C}$ for calcite and $50^{\circ} \mathrm{C}$ for dolomite. A correction of $-0.4 \%$ must be taken into account for the $\delta^{18} \mathrm{O}$-value of dolomite at a temperature of $50^{\circ} \mathrm{C}$ because of the difference in fractionation between calcite and dolomite in phosphoric acid (Nielsen, 1996). Analytical error is in the order of $<0.12 \%$ ( $2 \mathrm{~s})$ for oxygen and $<0.06 \%$ ( $2 \mathrm{~s}$ ) for carbon. All results are reported with reference to the PDB-standard.

\section{The Grande Dolomie de Namur Forma- tion $(130.3 \mathrm{~m}$ to $89.0 \mathrm{~m})$}

Within this formation, limestones and fine crystalline dolomites hosting columnar calcite horizons and zebra dolomites can be differentiated. Therefore the succession can be split up in several subunits according to their dominant lithology which will be discussed in different paragraphs below.

\subsection{The host rock limestone (111.4m to $89.0 \mathrm{~m})$}

\section{Description:}

From a sedimentological point of view two different microfacies can be distinguished. Microfacies A, which is especially well-developed in the upper $20 \mathrm{~m}$ of the succession, consists of a dolomitised mudstone to wackestone with fenestrae. The matrix is dominantly micritic with a few bioclasts and peloids. Locally calcified gypsum crys-

\begin{tabular}{|lcc|}
\hline & $\delta^{18} \mathrm{O}(\% \mathrm{o})$ & $\delta^{13} \mathrm{C}(\% 0)$ \\
\hline Chadian * & $-5.8 \pm 2.0$ & $+2.8 \pm 1.4$ \\
Arundian * & $-7.0 \pm 2.5$ & $+1.5 \pm 0.1$ \\
Tournaisian - Visean & $-4.6 \pm 1.5$ & $+2.8 \pm 1.4$ \\
Boundary ** & $-5.7 \pm 2.0$ & $+2.8 \pm 1.4$ \\
Accepted values & & \\
\hline
\end{tabular}

* Bruckschen and Veizer, 1997

** Bruckschen et al., 1999

Table 1. Reported oxygen and carbon isotope values for the transition of Tournaisian - Visean marine carbonates- 
tals have been identified. Microfacies B is composed of dolomitised peloidal to oolitic grainstone. Within some oolites relics of a radial texture are recognisable. However, strong micritisation masks many of the original textures. Numerous crinoids are also discernible, especially in the more intensively dolomitised lithologies.

An equant to blocky dull dark brown yellow to CL-zoned calcite cement (henceforth called $\mathrm{C} 1$; table 2) forms the first cement in the paragenetic sequence. It only occurs within fenestrae in the upper part of the sequence and is crosscut and covered by blocky calcites. Within the latter blocky calcite cements two types frequently occur in these limestones (especially in the grainstones), i.e. a dominantly non-luminescent blocky calcite (henceforth called C2) and a yellow-orange to orange-brown luminescent blocky calcite (called C3; table 2). The latter is locally characterised by sector-zonation. Both also occur as fracture fills. C3-cemented fractures have been observed to crosscut $\mathrm{C} 2$-cemented fractures. C3-cement thus post-dates $\mathrm{C} 2$-cement.

All three cement types ( $\mathrm{C} 1$ to $\mathrm{C} 3$ ) pre-date stylolitisation. They are cut by a weakly developed subhorizontal to slightly inclined stylolites as well as by a later generation of steeply inclined stylolites (henceforth called respectively $\mathrm{S} 1$ and $\mathrm{S} 2$; table 2). At least three $\mu \mathrm{m}$-thin frac- ture generations (one filled with dull brown luminescent calcite and two with bright luminescent calcite (respectively C4, C5 and C6 in table 2) post-date S2-stylolites. Notice that none of these fracture fillings or cement phases is ferroan.

As non-carbonate phases authigenic quartz and diagenetic pyrite have been observed. The former may possess a hexagonal prismatic outline with a central micrite-rich core. The quartz phases occur in spatial relationship with the stylolites and are cut by some of the fractures, postdating-S2 stylolites. This is also the case with the pyrite phases. Noteworthy is that some of the bright yellow luminescent fractures surround the pyrite crystals.

The $\delta^{18} \mathrm{O}$ - and $\delta^{13} \mathrm{C}$-values of the limestones vary between $-7.77 \%$ and $-12.60 \%$ PDB and between $-3.04 \%$ ond $2.09 \%$ PDB respectively (Fig. 3).

\section{Interpretation:}

The sedimentary features of the two observed microfacies indicate a low energy depositional environment (compare with Strasser, 1986). Boring micro-organisms most likely caused the strong micritisation of the oolites (Tucker \& Wright, 1990). This feature could indicate slow sedimentation rates. The numerous crinoids support a subtidal or open marine setting. The

\begin{tabular}{|c|c|c|c|}
\hline & general aspect & CL-characteristics/zonations & occurrence \\
\hline $\mathrm{C} 1$ & equant to blocky calcite & $\begin{array}{l}\text { dull DB / NL / } \mu \mathrm{m} \text { thin bright Y / } \\
\text { dull DB }\end{array}$ & $\begin{array}{l}\text { in some fenestrae, in top part } \\
\text { Grande Dolomie }\end{array}$ \\
\hline D1 & xenotopix-A to idiotopic-S dolo. & $\begin{array}{l}\text { purple inclus.-rich core, dull red } \\
\text { inclus.-poor rim }\end{array}$ & matrix dolomite \\
\hline $\mathrm{C} 2$ & blocky calcite & $\begin{array}{l}\text { dom. NL with few bright Y lum. } \\
\text { crystal } \\
\text { terminations }\end{array}$ & $\begin{array}{l}\text { in fenestrae, calcispheres, } \\
\text { intraparticular } \\
\text { in oolites, interparticular and as } \\
\text { fracture infill }\end{array}$ \\
\hline $\mathrm{Z}$ & zebra dolomite (abba banding) & dull orange-red spotted & In lowermost part of borehole \\
\hline $\mathrm{C} 3$ & blocky calcite & dull YO to OB, with sector zonation & $\begin{array}{l}\text { filling remaining pores after } \mathrm{C} 2 \text { - } \\
\text { cementation, as fracture infill cutting } \mathrm{C} 2\end{array}$ \\
\hline D2 & fringing cement & dull $\mathrm{R}$ to bright $\mathrm{R}$ & minor phase, cavity filling \\
\hline S1 & subhor. to weakly inclined & l & weakly developed \\
\hline $\mathrm{S} 2$ & steeply inclined & l & sometimes $100 \mu$ m-thick seams \\
\hline D3 & fringing cement & lilac & minor phase, cavity filling \\
\hline Q & authigenic quartz crystals & $\begin{array}{l}\text { NL } \\
\text { stylolites }\end{array}$ & clustered around $\mathrm{S} 1 \& \mathrm{~S} 2$ \\
\hline $\mathrm{C} 4$ & equant calcite & dull Y to B & $\mu \mathrm{m}$-thin fractures \\
\hline $\mathrm{C} 5$ & equant calcite & bright $\mathrm{Y}$ to $\mathrm{OY}$ with darker spots & $\mu \mathrm{m}$-thin fractures \\
\hline Py & authigenic pyrite & NL & dull orange-red \\
\hline C6 & equant calcite & bright Y & several $\mu \mathrm{m}$-thin fractures \\
\hline
\end{tabular}

Table 2. Main characteristics of the most important diagenetic products in the carbonate host rock of the Grande Dolomie de Namur Formation:

C1 to S2 in paragenetic order, relationship S1 - Z unclear, C4 to C6 post-date S2 but mutual paragenetic succession unknown, D3 S2 relationship unknown

Abreviations: dolo= dolomite; dom.= dominantly; subhor.= subhorizontal; inclus= inclusion; $\mathrm{NL}=$ non-luminescent; $\mathrm{DB}=\mathrm{dark}$ brown; $\mathrm{Y}=$ yellow; $\mathrm{YO}=$ yellow orange $\mathrm{OB}=$ orange brown; $\mathrm{R}=\mathrm{Red}$ 


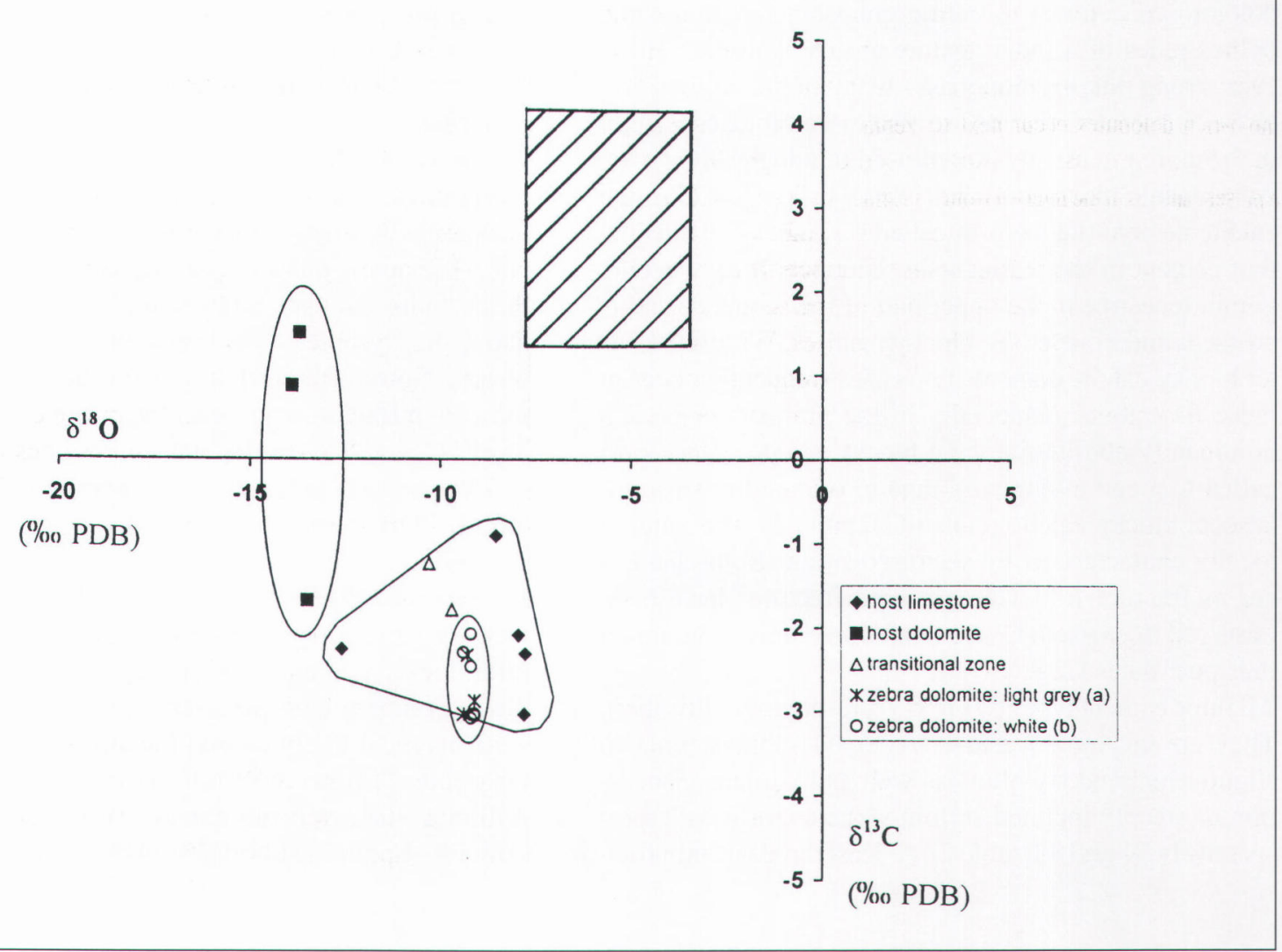

Figure 3. Stable isotope plot of host rock limestone and dolomite as well as zebra dolomites of the Grande Dolomie de Namur. The hashed area represents the reference area of the marine Lower Carboniferous limestones.

development of fenestral limestones with a limited fauna in the upper part of the succession points to a shallower restricted environment. This interpretation is also supported by the local existence of pseudomorphs after evaporite minerals.

A question to be addressed here is the fact that an important emersion phase inducing karstification of the top of the 'Grande Dolomie de Namur' Formation, as described by Damiaen (1956) and others (for references see Nielsen et al., 2001), has not been recognised as such in the studied borehole. However, it is well-expressed in nearby outcrops. The fact that the 'Encrinite de Flémalle' and the 'Avins Limestone' Formations have not been recognised in this borehole support the existence of an important stratigraphical gap. The development of karst cavities over a vertical interval of at least $40 \mathrm{~m}$ as documented below also supports the existence of a sedimentation hiatus.

From a diagenetic point of view the development of stylolites is of major interest. Stylolites are here used to constrain the timing of cementation and fracturation events. The subhorizontal S1-stylolites developed during the footwall subsidence of the sedimentary basin before important tectonic deformation occurred. They thus are compactional in origin. When and at what depth they exactly formed is unknown. According to Helsen and Königshof (1994) a Conodont Alteration Index-value of 3.5 is typical for Lower Carboniferous strata near the town of Namur. Teichmüller and Teichmüller (1979) measured $2.8 \%$ Rmax-values in this area. Both values support a maximum burial temperature of $140-160^{\circ} \mathrm{C}$, which might correspond to burial depths of 4-5 Km. Helsen and Königshof (1994) support a maximal burial at the end of the Carboniferous. Thus cements $\mathrm{C} 1$ to $\mathrm{C} 3$ formed before the development of S1-stylolites and thus are preVariscan in origin. The steeply inclined S2-stylolites relate to layer parallel shortening (LPS) during the Variscan deformation (compare Hudleston and Holst-Timothy, 1984; Van Geet et al., 2001). The late stage development of $\mathrm{C} 4$ - to C6-cements and vein infill is deduced from the fact that these cements post-date LPS-stylolite (S2) development. They are interpreted as syn- or post-Variscan in origin. The fact that the latter two vein-types are bright yellow luminescent is in line with this interpretation, since this luminescence is often explained by the late-diagenetic co-precipitation of pyrite and calcite. The bright yellow luminescence nature of late stage cements and fractures is often linked in literature to thermal sulphate reduction (TSR). The latter is considered here as the S-source which 
in combination with $\mathrm{Fe}^{2+}$ liberated from clay mineral transformations will form pyrite. According to Machel et al. (1995) TSR only occurs at temperatures $>100$ $140^{\circ} \mathrm{C}$. By the formation of pyrite, $\mathrm{Fe}^{2+}$ is removed from the fluid. Consequently iron, which is considered to be one of the main luminescence inhibitors (Machel, 2000), will no longer be incorporated in the calcite lattice, and the higher $\mathrm{Mn} / \mathrm{Fe}$ ratios will induce the bright yellow luminescence. Based on the spatial distribution of pyrite and authigenic quartz these minerals precipitated out of fluids, which were preferentially channeled along stylolite seams. Both minerals might relate to clay diagenesis, whereby the smectite to illite conversion may be one of the dominant processes releasing $\mathrm{Mg}^{2+}$ and $\mathrm{Fe}^{2+}$ in the subsurface. This clay transformation is only known to occur under deep $(<1 \mathrm{~km})$ burial conditions.

The stable isotope characteristics of the analysed limestones shows that they are depleted with respect to Lower Carboniferous marine carbonates (compare with data presented in table 1). Similar ${ }^{18} \mathrm{O}$-depleted values have been observed in the Statte-Flémalle Anticline situated in the direct footwall of the Variscan thrust front by Muchez et al. (1995; 2000). These values can on the one hand be explained by re-equilibration within a closed fluid system during which the host rock limestones, which were originally deposited in a marine environment, underwent meteoric diagenesis. On the other hand recrystallisation at elevated temperatures during burial or due to interaction with isotopically depleted formation water could also be invoked (compare with Lohmann, 1987). The deviation of the $\delta^{13} \mathrm{C}$-values with respect to marine Lower Carboniferous carbonates might support the burial hypotheses. According to Bottinga (1968) and Emrich et al. (1970) a temperature related fractionation of $0.04 \%{ }^{\circ} \mathrm{C}$ occurs. Thus if recrystallisation occurred at temperatures $>100^{\circ} \mathrm{C}$, a shift in the carbon isotopic composition of $-4 \%$ is possible. In this scenario also the interaction with ${ }^{12} \mathrm{C}$-enriched fluids derived from decarboxylisation reactions generated during burial diagenesis could be invoked. However, if these processes are able to alter the carbon isotopic signature of the limestones they should be more commonly recognised in limestones which were deeply buried. The nearby Dinantian limestones of StatteFlémalle as well as time-equivalent limestones in the Verviers synclinorium, for example, are not depleted in ${ }^{13} \mathrm{C}$. Their $\delta^{13} \mathrm{C}$-values range from 0 to $+3 \%$ (Muchez et al., 1995). These limestones, however, do not occur close to a major karst horizon. Therefore the following interpretation is preferred: during the period of intensive karstification, fluid interaction with ${ }^{13} \mathrm{C}$-depleted soilderived $\mathrm{CO}_{2}$ happened, which also caused some ${ }^{13} \mathrm{C}$ depletion of the limestones interacting with these fluids. This depleted $\delta^{13} \mathrm{C}$-signature, with respect to the original marine signature, seems to have been preserved during diagenesis.

\subsection{The host dolomites (130.3m to $89.0 \mathrm{~m})$}

\section{Description:}

Dolomites occur in three intervals, i.e. (1) below $115.25 \mathrm{~m}$ crinoid-rich dolomites occur next to zebra dolomites, (2) between $115.25 \mathrm{~m}$ and $111.4 \mathrm{~m}$ massive dolomites are present and (3) in the interval from $111.4 \mathrm{~m}$ to $89.0 \mathrm{~m}$ limestone with centimeter thick dolomite intercalations occur. The zebra dolomites will be described in the next section.

Different limestone relics in the dolomites testify to the fact that a wide variety of limestone types have been dolomitised. The dolomites are thus secondary in origin. According to the classification of Gregg and Sibley (1984) the host rock dolomites have a dominantly xenotopic-A to idiotopic-S texture (plate I.3). An idiotopic-C texture occurs in cavities. The crystal dimensions generally vary between $80 \mu \mathrm{m}$ and $500 \mu \mathrm{m}$ and are largest for the crinoid-rich intervals. Locally subhedral to euhedral dolomite rhombohedra float in C3-calcite cement (Plate I.3) giving rise to an idiotopic$\mathrm{P}$ texture. Here C3-calcite cementation occurred in intercrystalline pores and thus post-dates dolomitisation (Plate I.4). In general based on thinsection observations the dolomites have $<5 \%$ intercrystalline porosity. Cavities 0.5 to $5 \mathrm{~mm}$ in diameter are often totally filled with $\mathrm{C} 3$-cement except in the crinoid-rich host dolomite. Here the crinoid moulds are not cemented.

Cathodoluminescence observations allow to recognise one major limestone replacive dolomite phase (henceforth called D1). It has a dirty brown appearance under transmitted light, and a purple luminescent (inclusionrich) core with a dull red luminescent (inclusion-poor) rim (Plate I.3). Thin dolomite cements with similar luminescence features have also been recognised as intraparticle or cavity-filling phases. Wispy luminescence textures and red luminescent inclusions in these dolomites often occur (Plate I.4). Despite the fact that S1- and S2stylolites are less developed in the dolomitised lithologies, locally their crosscutting relationship indicates that D1-dolomitisation pre-dates S1 and thus also S2-stylolite development.

Additionally two other replacive dolomite phases (henceforth called D2 and D3; table 2) have been identified by CL-petrography. They also locally may have caused some of the $\mu \mathrm{m}$-thin dolomite cement phases (Plate I.3). Both are clearly volumetrically less important than D1. D2 is crosscut by stylolites and post-dates $\mathrm{C} 2$-cementation and fracture filling, while the relationship between D3 and the stylolites is not clear. The latter dolomite phase, however, certainly formed after C3-calcite cementation and fracture filling since some of these D3-dolomites replaced C3 cement.

Another characteristic aspect of the host rock dolomites is the development of dedolomitisation and dissolution textures. There exists a clear spatial rela- 
tionship between dedolomitisation and the development of C2- and C3-calcite cement. Based on this spatial relationship at least two episodes of dolomite alteration are recognised. The fluids preceding or precipitating C2- and C3-cements are thus likely candidates for dedolomitisation and/or dolomite dissolution. These processes will be addressed in more detail when the columnar calcites are discussed. There is also a later dedolomitisation/dissolution event recognised in association with the development of C6-calcite. The other calcite fracture fills have not been identified in the dolomitised lithologies. Notice that the xenotopicA dolomites are more prone to dissolve than the idiotopic-S dolomites.

The stable oxygen and carbon isotope values of 3 analysed host rock dolomites vary between $-13.15 \%$ and $13.52 \%$ PDB for $\delta^{18} \mathrm{O}$ and between $-1.68 \%$ and $+1.50 \%$ o PDB for $\delta^{13} \mathrm{C}$ (Fig. 3).

\section{Interpretation:}

The petrographical characteristics of these dolomite rocks are very similar to the outcropping dolomite lithologies in the Méhaigne, Liège-Verviers and Aachen area, which were described by Nielsen et al. (1994) and Nielsen (1996). Its pre-compactional origin, based on the crosscutting relationship with bedparallel stylolites, has been recognised at many places. An eogenetic origin is therefore very likely. This was also deduced from the fact that on a regional scale (Chokier-Liège area) the karst cavities at the top of these dolomites are geopetally filled by crinoidal sediments of the 'Encrinite de Flémalle' Formation. The latter formation and the replaced limestones are assumed to be of Upper Tournaisian and perhaps even Lower Visean age (L. Hance: personal comm.). Since the geopetal infill is not dolomitised, dolomitisation and karstification are Upper Tournaisian/Lower Visean in age (Nielsen, 1996). Notice however, that in the studied borehole, no similar sedimentary fills have been observed in the karst cavities.

Based on their eogenetic formation and the general geological setting two dolomitisation models can be put forward. In the first scenario dolomitisation relates to the development of a mixing zone which induces a circulation of seawater through the sea-bed sediments (compare with Muchez and Viaene, 1994). This model can be argumented by the marked changes in sea-level which generated the important karst system at the top of the dolomites, especially if one considers that these karst cavities reach several tens of meters downward as is the case in the Namur syncline. In this case, its development most likely occurred under humid climatic conditions, inducing important fluid circulation. Reflux dolomitisation is a likely second scenario. Here dolomitisation occurs by marine or hypersaline fluids under arid to semi-arid conditions. This model, first proposed by Swennen (1984), is supported by the fact that time- equivalent dolomites in the eastern part of Belgium are surmounted by thick evaporite collapse breccias (Swennen et al., 1990). Also the general evolution towards more restricted sedimentation conditions reflected by the presence of fenestral lithologies with evaporite pseudomorphs support this model. Within many karst fillings of the Plombières borehole (E-Belgium) crosscutting the upper dolomite interval pseudomorphs after lozenge shaped evaporite minerals are present. The latter possess displacive growth features. Within the surrounding host rocks they are absent most likely because the latter were already lithified. In "les Avins", depressions at the top of the "Grande Dolomie de Namur' Formation, which have tentatively been interpreted as karst depressions, contain oolitic sediments with locally numerous pseudomorphs after diagenetic evaporite minerals. The latter are clearly precompactional in origin since they are crosscut by subhorizontal stylolites. These observations indicate that both dolomitisation models, i.e. mixing zone and reflux dolomitisation may have been superimposed on one another.

None of the above dolomitisation models, however, is supported by the isotopic compositions of the dolomites. The $\delta^{18} \mathrm{O}$-values are therefore too depleted. Values of $13.15 \%$ to $-13.52 \%$ o PDB for $\delta^{18} \mathrm{O}$ are not in line with an early diagenetic, i.e. eogenetic origin of these dolomites. Similar values and observations have been reported by Nielsen et al. (1994). They were interpreted to represent multi-phase recrystallisation (see also Kupecz et al., 1993; Smith \& Dorobek, 1993). The recrystallisation hypothesis for the Vinalmont dolomites is also supported by the wispy luminescence features observed under CL and by the fact that different types of late diagenetic fluid circulated through these dolomites as manifested by the $\mathrm{C} 4$ - to $\mathrm{C} 6$-fracture fills. In the studied borehole the $\delta^{18} \mathrm{O}$-values plot remarkably close to each other. As far as these three analyses are representative, they point to a rather uniform recrystallisation history. The latter caused a reequilibration of the oxygen isotopic signature, whereby circulation of hot fluids during burial diagenesis is the most likely scenario. The $\delta^{13} \mathrm{C}$-values plot within or close to the range of Lower Carboniferous marine carbonates. The one sample with the most depleted signature was a sample taken close to the karstified limestone. Possibly, this may explain this value since the limestones are generally more depleted in $\delta^{13} \mathrm{C}$ as discussed above. In general the carbon isotopic signature of the limestones seems to have been retained during dolomitisation. Nor was it significantly altered during karstification or recrystallisation.

For a discussion with regard to the development of corrosion/dedolomitisation aureoles around the $\mathrm{C} 2$ - and C3calcite cemented zones and the $\mathrm{C} 3$-calcite cementation of the dolomite we refer to the discussion below where we will address the origin of the columnar calcites. 


\subsection{Zebra and saddle dolomites (130.3m to $115.25 \mathrm{~m})$}

\section{Description:}

The zebra dolomites are composed of a repetition of irregular, subhorizontal, light-gray (a) and white (b) dolomite 'bands'. The 1 to $10 \mathrm{~mm}$ thick, subhorizontal 'bands' are not necessarily parallel to stratification. They make up a diagenetic rhythmicity of the type 'abbabba'. A lightgray alteration zone forms the contact between the zebra dolomites and the crinoidal host dolomites. The white zebra 'bands' can often not be traced over the whole core width $(5.5 \mathrm{~cm}$ in diameter $)$. In the center of the white 'bands', cavities with a length of 0.5 to $30 \mathrm{~mm}$ and a width of 0.5 to $10 \mathrm{~mm}$ are locally present. In these cavities saddle dolomite crystals with a xenotopic-C texture developed. Away from the cavities, an idiotopic-S (Plate I.1 \& 2) to xenotopic-A texture is often present. The crystals generally display sweeping extinction. The mean crystal diameters in the zebra dolomites are larger (up to $1 \mathrm{~mm}$ adjacent to cavities) than in the crinoidal host dolomites (250-320 $\mu \mathrm{m})$. With the exception of slight differences in crystal sizes, the macroscopic distinctive white and dark zebra 'bands' do not display differentiable characteristics under transmitted light-microscopy or cathodoluminescence. Both the (a) and (b) crystals possess a dull orange-red luminescence with bright luminescent spots (Plate I. 1 \& 2). The spotted nature is dominantly caused by solid inclusions in the crystals. Within cavities the inclusionfree crystal terminations display a dull orange-red CL-zone with numerous bright luminescent spots succeeded by a CL-zone with alternating dull orange-red and darker, relatively thin luminescent, CL-subzones (Plate I.1 \& 2). Typical feature is the existence of jigsaw-dislocations within both CL-zones (Plate I.2). This texture, which also has been described by Nielsen et al. (1998) as microfractured rims, shows that microfracturation is concomitant with cementation. These microfractured cements are subsequently covered first by a few $\mu \mathrm{m}$-thin dull brown to nonluminescent phase (possibly ankerite) (Plate I.1 \& 2) and subsequently by a $\mu \mathrm{m}$-thin bright orange calcite luminescent phase. Based on similarity in luminescence characteristics the latter might correspond to one of the late diagenetic C5- or C6-calcite phases. The relationship between zebra dolomite and stylolitisation is not very clear. Only at one place a steeply inclined S2-stylolite crosscuts the zebra bands which places zebra formation before LPSstylolite development. Hexagonal to irregular diagenetic quartz crystals and pyrite crystals cluster around the stylolites as described above. Authigenic pyrite and quartz also cover the dull brown to non-luminescent cavity cementing (possibly ankerite) phase.

The stable isotope values of the white and gray 'bands' vary between $-9.1 \% \circ$ and $-9.4 \% \circ \mathrm{PDB}$ for $\delta^{18} \mathrm{O}$ and between $-2.08 \% \circ$ and $-3.09 \%$ PDB for $\delta^{13} \mathrm{C}$ (Fig. 3). No distinction can be made between the white or dark 'bands'. Stable isotope values of the transitional zone between host dolomites and zebra dolomite are also transitional between the isotope clusters of both lithologies (Fig. $3 ; \delta^{18} \mathrm{O}$-values of $-9.7 \%$ and $-10.3 \%$ PDB and $\delta^{13} \mathrm{C}$-values of $-1.24 \%$ and $-1.79 \%$ PDB). One zebra-dolomite sample was analysed microthermometrically, whereby fluid inclusions were studied in the grey (a) and white (b) dolomite bands. In the white dolomite bands both the inclusion-rich and inclusion-poor, microfractured CL-zones where analysed. The mean homogenisation temperature of all above described dolomite phases are similar and cluster around $115^{\circ} \mathrm{C}$ (Fig. 4). Unfortunately due to the small inclusion size no ice-melting temperatures could be measured.

\section{Interpretation:}

The rhythmic banding (abbabba) is clearly diagenetic in origin, and is the reason why zebra dolomites are also described as 'diagenetic crystallisation rhythmites' (Fontboté and Gorzawski, 1990; Fontboté, 1993). The petrography as well as the isotopic signatures and homogenisation temperatures of the above described dolomites are comparable to features reported for the zebra dolomites of Soumagne and Soiron (Synclinorium of Verviers) which have been studied more intensively by Nielsen et al. (1998). According to these authors the formation of the zebra dolomites is related to suprahydrostatic fluid pressures generated in a compressional regime during the Variscan orogeny (Nielsen et al., 1998). Subhorizontal extensional microfractures and cavities are formed and kept open by the (suprahydrostatic) fluids derived from numerous steep thrust faults. The microfractures and cavities are responsible for the regular 'bands' of the zebra dolomites. The zebra dolomites of Vinalmont are explained in a similar way, especially since intracrystalline microfissures in cement phases have been recognised as well as porosity development in the burial realm.

The fact that the $\delta^{18} \mathrm{O}$ - and $\delta^{13} \mathrm{C}$-values for the white and gray 'bands' are identical indicates that they formed by a similar process. The depleted $\delta^{18} \mathrm{O}$-values are in line with

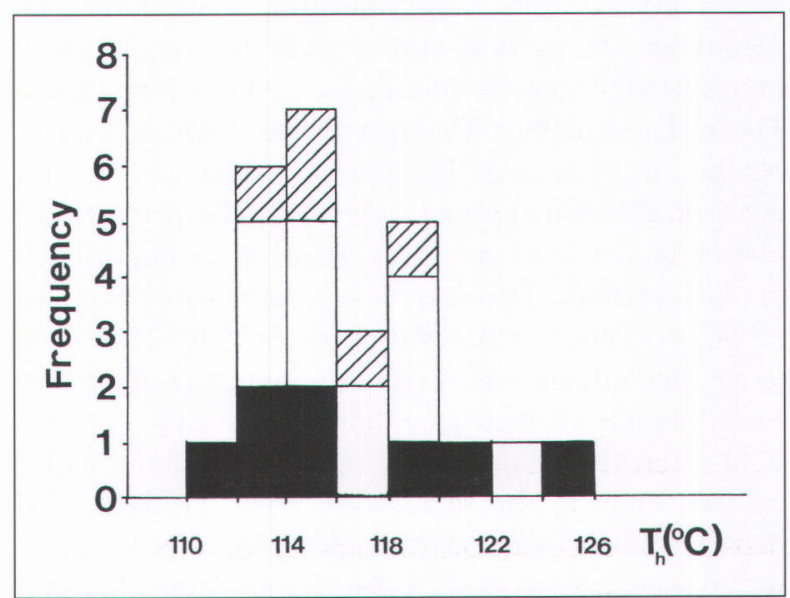

Figure 4. Homogenisation temperatures of primary fluid inclusion of columnar 2 crystals $($ black $=$; white $=$; hashed $=$ ). 
the high homogenisation temperatures. No pressure correction to these homogenisation temperatures has been applied since it is not sure that the dolomitising fluids were in temperature and pressure equilibrium with their host rocks during formation, due to their suprahydrostatic nature. However, if chemical equilibrium is assumed and based on the fractionation equation of Machel and Burton (1994) using a mean $\delta^{18} \mathrm{O}$-value of $-9.25 \%$ PDB with a formation temperature of $115^{\circ} \mathrm{C}$, a $\delta^{18} \mathrm{O}$-value of $+3.2 \%$ o SMOW can be calculated for the fluid involved in zebra formation. Such high values support fluid interaction with basement rocks. This is in line with the model proposed by Heylen et al. (2000) where part of bittern brines that formed during the Middle to Late Paleozoic migrated down into the basement until they were episodically expelled along faults during the Variscan orogeny and later during several periods in the Mesozoic.

In comparison with the host rock dolomite the $\delta^{18} \mathrm{O}$-values of the zebra dolomites are more enriched in ${ }^{18} \mathrm{O}$ and the $\delta^{13} \mathrm{C}$-values are more depleted in ${ }^{13} \mathrm{C}$. The transitional zone between both lithologies possesses an isotope signature along a mixing line (Fig. 3). The fact that both dolomite lithologies define separate clusters with respect to their stable isotope signature supports the hypothesis that isotopic resetting of the host rock dolomites was not caused by interaction with zebra-type dolomitising solutions. Both processes are thus unrelated. From the borehole of Plombières (E-Belgium) we know that a saddle dolomite phase with $\delta^{18} \mathrm{O}$-values as low as $-20 \%$, predates the zebra related saddle dolomites (Nielsen, 1996). The fluids precipitating these saddle dolomites have been interpreted to be responsible for dolomite recrystallisation in the latter area. Although the latter saddle dolomites have not been recognised in the Vinalmont core, it is possible that the highly negative $\delta^{18} \mathrm{O}$-values of the host dolomites might also relate to interaction with these type of fluids. The narrow stable isotope range of the zebra dolomites also supports the hypothesis that they formed after recrystallisation of the host rock. Alternatively the zebra dolomites may not have been prone to recrystallise during recrystallisation of the host rock dolomites. The fact that they pre-date S2-stylolites may indicate that the zebra dolomites are pre- or syntectonic. The depletion of the $\delta^{13} \mathrm{C}$-values can be explained by temperature fractionation during burial diagenesis. Accepting a precipitation temperature of $115^{\circ} \mathrm{C}$ allows to explain a shift of $\delta^{13} \mathrm{C}$ of $-5.6 \%$ PDB from the original marine signature, if the fractionation equation of Bottinga (1968) or Emrich et al. (1970) is used. This is, however, in conflict with the carbon isotopic signature of the host rock dolomites, which according to their more depleted $\delta^{18} \mathrm{O}$-signature would impose at least similar negative carbon values as the zebra dolomites. Introduction of depleted bicarbonate derived from decarboxylation, which were transported by the dolomitising fluids, is therefore the preferred explanation for the depleted carbon signature of the zebra dolomites.

\subsection{The Columnar Calcite Horizons (126.4m to $89.4 m)$}

\section{Description:}

Within the upper part of the host rock dolomites, the socalled columnar calcites occur. They consist of nonferroan elongated calcite crystals lining centimeter to decimeter large cavities. Either the cavities are filled by one generation of elongated crystals or several growth phases (up to five) can be recognised (Plate I.5 \& 6). Here clay seams locally border the growth phases. Generally the crystals developed perpendicular to the cavity walls (Plate I.5), implying that they developed in all directions. At the base of the crystals locally a kind of debris, i.e. internal sediment, consisting of calcite, dolomite and quartz grains is discernible. Within the Vinalmont borehole, these columnar crystals have been recognised from a depth of 126.4 to $89.4 \mathrm{~m}$.

The crystals range in size typically from 0.1 to $10 \mathrm{~mm}$ and can be classified as radiaxial-fibrous sensu Kendall (1985) (Plate I.6). The length:width ratio of these crystals varies between $3: 1$ to $15: 1$, with ratios of $5: 1$ to $7: 1$ being the most common. They normally broaden in growth-direction. The contact between the different crystals is well-defined. Crystal terminations can be welldeveloped, however, some of them are rounded and corroded. These crystals normally exhibit a uniform extinction and are length-fast. They thus can be described as radiaxial. Twinned crystals have been observed, but they are very uncommon. However, cleavage twins are omnipresent. Apart from the columnar crystals also equant textures occur. These are the result of an oblique to perpendicular section through the columnar crystals. Cathodoluminescence observations allow differentiating two types of columnar crystals. A first generation (henceforth called columnar 1) is generally non- to dull dark brown luminescent (Plate II.2 \& 3), with the exception of some $\mu \mathrm{m}$-thin crystal overgrowths, which display various brown-orange to brown-yellow luminescent growth zones. It is within this calcite generation that growth bands commonly developed and that microsparite grains and detrital quartz cover the latter growth bands (Plate I.6). The micrite/microsparite mainly fills depressions in the micro-topography between well-developed protruding crystal terminations (Plate I.6 \& II.1). This columnar 1calcite generation is considered to be equivalent to the C2-calcite described above.

The second generation (henceforth called columnar 2) is dull yellow orange to orange brown luminescent (plate II. 2 \& 3). Locally minute red luminescent dolomite and bright yellow luminescent calcite inclusions occur within the normally rather elongated mono-crystals. Here, no cyclic growth bands separated by detritals are developed. This columnar 2-calcite generation is identical to the $\mathrm{C} 3$ calcite described earlier. The contact between both columnar calcite generations is always very sharp with the columnar 2 occurring always as latest phase. This is es- 
pecially apparent in some of the equant crystal textures where the triangular core is non- and the overgrowth phase is dull yellow orange to orange brown luminescent (Plate II. 2 \& 3). Sometimes a corrosive contact between both phases can be recognised. This contact is also sometimes accentuated by the development of pyrite crystals (Plate II.3). Another argument supporting the time-relationship of both calcite generations is that within columnar 1-calcite crystals sometimes whimsical dull yellow orange luminescent patterns developed, which testify of an alteration by columnar 2-fluids. Also fractures filled by $\mathrm{C} 3$ cements (Plate II.3) and columnar 2-crystals crosscut the first columnar calcite generation. Finally, columnar 1and 2-phases are crosscut by bright yellow calcite phases, which are equivalent to calcite cement $\mathrm{C} 5$ or $\mathrm{C} 6$.

Noteworthy is also that the host rock next to the columnar calcites always has been altered. The limestone host rock is completely recrystallised to microspar, while in dolomite host rock locally a dedolomitisation aureole developed.

Another interesting observation is that locally cracks occurring in a zebra dolomite interval are filled by the second columnar calcite generation, placing zebra dolomite formation before the $\mathrm{C} 3$-calcite cementation. However, this was only observed at one location. Subhorizontal S1-stylolites clearly affect cavities filled by columnar 1-calcite and mm-broad fractures filled by C3-calcite and columnar 2-calcite do not crosscut these stylolites. This suggests that S1-stylolites developed afterwards. An inclined S2-stylolite clearly transects a cavity filled by columnar 1-calcite. Columnar 2-crystals close to $\mathrm{S} 2$-stylolites display deformation cleavage textures.

The $\delta^{18} \mathrm{O}$ - and $\delta^{13} \mathrm{C}$-values of columnar 1-calcites vary between $-6.5 \%$ and $-10.3 \%$ PDB and between $-2.5 \%$ o and $-4.8 \%$ PDB respectively. Important feature is that crystals, which display recrystallisation features (i.e. dull yellow orange luminescent features due to alteration by columnar 2), always have $\delta^{18} \mathrm{O}$-values below $-8.0 \%$. No major variations have been recognised between subsequent growth bands or with the intercalated microsparite laminae. Notice that the columnar 1-calcites roughly cover a same range in $\delta^{18} \mathrm{O}$-values than the host rock limestones and are somewhat more depleted in $\delta^{13} \mathrm{C}$. The columnar 2-calcites possess $\delta^{18} \mathrm{O}$-values in the range of 16.2 to $-16.7 \%$ PDB and $\delta^{13} \mathrm{C}$-values in the range of +0.07 to $-1.17 \%$ o PDB (Fig. 5).

\section{Interpretation:}

The columnar calcites 1 and 2 are in analogy with Nielsen et al. (2001) interpreted to represent respectively palaeospeleothems and products of hydrothermal karstification. The reader is referred to this paper for detailed argumentation on the origin of the columnar calcites. Here only the most relevant arguments are briefly enumerated.

The palaeo-speleothem origin for the columnar 1-crystals is supported by (1) the existence of growth bands

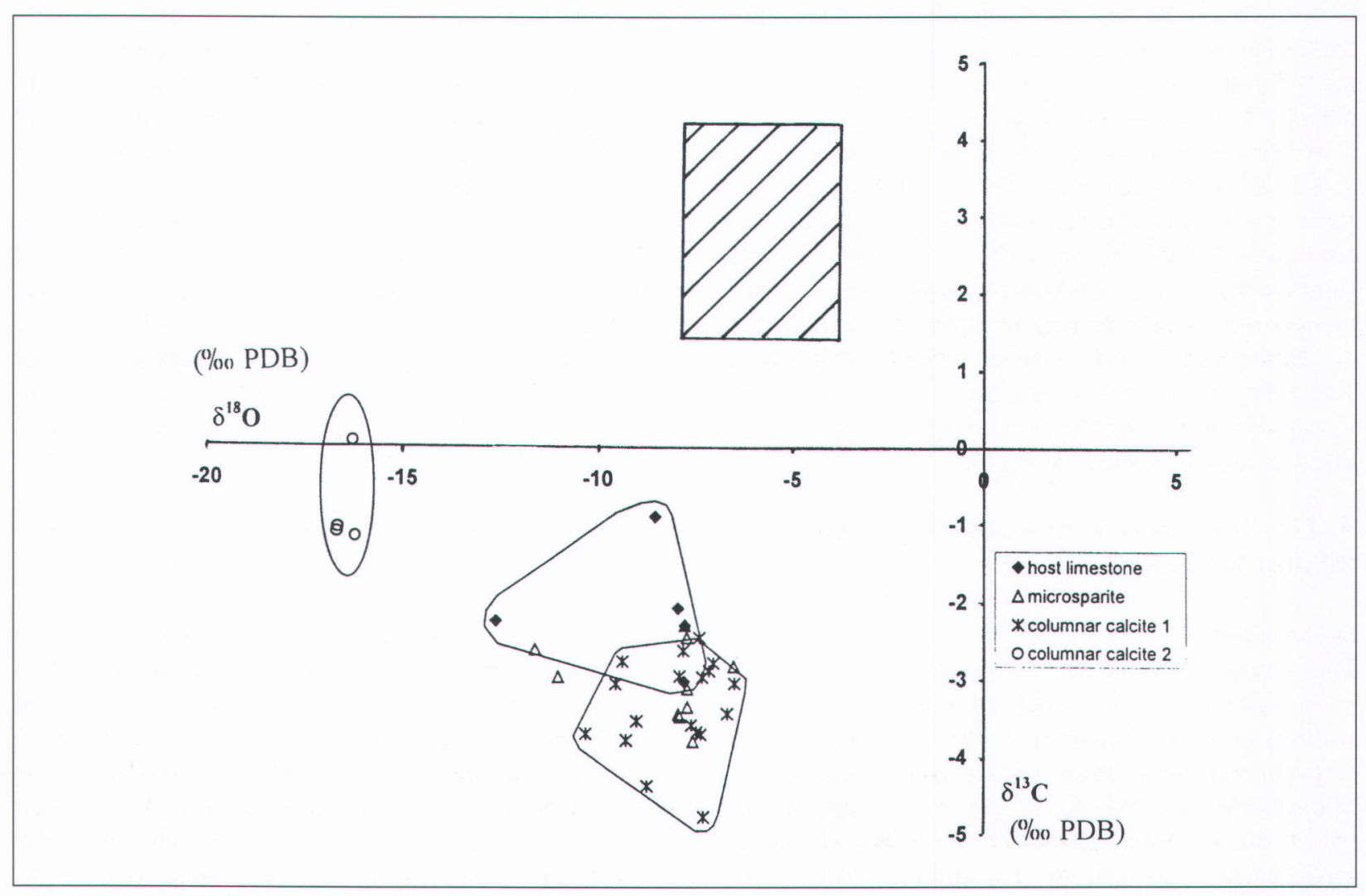

Figure 5. Stable isotope plot of host rock limestone of the Grande Dolomie de Namur with special emphasis to karst infill phases. The hashed area represents the reference area of the marine Lower Carboniferous limestones. 
with interlaminae microsparite and detritals sedimenting on top of newly formed crystals, (2) their development within dissolution cavities, (3) their dominant non-luminescent nature, (4) their stable oxygen signature which plots within the field of meteoric calcite formed during the Dinantian (compare with Walkden and Williams (1991) and Muchez et al. (1992; 1993)), (5) their depleted stable carbon signature which supports the presence of soil derived $\mathrm{CO}_{2}$ during columnar crystal growth. Their circumcavity development supports that the cavities were sometimes entirely filled with water. Karst cavity development and soil formation is placed during the intraUpper Tournaisian / Lower Visean emergence period. Interaction of the meteoric water along the cavities caused recrystallisation/dedolomitisation. It is very likely that during this period the original signature of the host rock limestones has been reset as suggested above. Curiously enough, the dolomite host rock does not reflect this signal in a similar way.

The hydrothermal karst origin of the columnar 2-calcites is based on (1) their distribution and development in cavities, (2) their very depleted oxygen isotopic composition, which points to the involvement of hot fluids, (3) their elevated homogenisation temperature as reported by Peeters et al. (1992) and Nielsen et al. (2001), (4) their slightly depleted carbon isotopic signature, and (5) the absence of growth bands in these elongated mono-crystalline crystals. Nielsen et al. (2001) additionally provide the following arguments based on outcrop observations: (1) the volumetrically important development of these columnar crystals giving rise to apparently floating dolomite beds, (2) the absence of any internal sediment fill in this huge cavity system, (3) their radiogenic ${ }^{87} \mathrm{Sr} /{ }^{86} \mathrm{Sr}$ signature with values between 0.7092 and 0.7104 . According to their model, pre- and synkinematic fluid circulation preferentially occurred along the palaeokarst contact between dolomites and limestones. Here cooling of formation waters was proposed as a likely model to explain the cavity development prior to columnar calcite precipitation (see also Giles and de Boer, 1989). The timing of this event is constrained by the fact that stylolitisation and the development of intra-crystalline deformation textures affect these columnar crystals.

\section{The Terwagne Limestone Formation (89.0m to $65.5 \mathrm{~m})$}

\section{Description:}

The selected samples allow to distinguish three major microfacies namely (1) bioclastic mud- to wackestone with scarce ostracods and calcispheres, (2) peloïdal packto grainstone with pellets, micritised radial oolites, calcispheres, ostracod-fragments and green algae and (3) palaeosols and subaerial crusts. The latter will be described in more detail below. The difference between the palaeosol and the subaerial crusts relates to the development of particular sedimentary features. Typical for all these lithologies is the limited variability in fauna content.

One of the major diagenetic characteristics of the Terwagne Limestone Formation is the limited development of matrix cements and the widespread development of fractures. Three types of fracture filling cements have been differentiated based on crosscutting relationships. Unfortunately, their similar orange brown luminescence with development of sector zonation makes individualisation of each fracture type under cathodoluminescence difficult. However one of the fracture types is slightly ferroan.

The dolomites within this limestone succession often have a brecciated appearance, due to selective dolomitisation of the strata. The diameter of the dirty brown dolomite crystals varies between $40 \mu \mathrm{m}$ and $160 \mu \mathrm{m}$ displaying a xenotopic-A to idiotopic-S fabric. Crystal sizes increase to $80 \mu \mathrm{m}$ and $320 \mu \mathrm{m}$ in the idiotopic-P intervals. Relics of allochems indicate that the dolomites are secondary and thus replacive in origin. Their spotted reddish luminescence likely reflects recrystallisation. An exact relation between the different diagenetic phases could not be established.

The $\delta^{18} \mathrm{O}$ - and $\delta^{13} \mathrm{C}$-values of the limestones range from -8.0 to $-7.6 \%$ PDB and -0.77 to $0.05 \%$ o respectively. The fracture infills and dolomites have not been analysed.

\section{Interpretation:}

The fauna and facies characteristics of these lithologies indicate a restricted shallow sedimentation environment. Highly micritised oolites, which locally occur, point to deposition in a low energetic, shallow marine environment. The presence of subaerial crusts and a palaeosol reflect regressive cycles ending in a continental phase. These features are in line with similar observations made by other authors for this formation (e.g. Maes et al., 1988; Peeters et al., 1992).

Despite the marine origin of the Terwagne Limestone, its stable oxygen isotope composition clearly reflects a meteoric overprinting, with values typically in the range of meteoric calcite formed during the Dinantian (compare with Walkden and Williams (1991); Muchez et al. (1992; 1993)).

\subsection{The palaeosol (66.95m to $67.32 \mathrm{~m})$}

\section{Description:}

Below a present-day karst cavity of $90 \mathrm{~cm}$ in thickness a $37 \mathrm{~cm}$ thick brecciated horizon occurs between $66.95 \mathrm{~m}$ to $67.32 \mathrm{~m}$. Within and below this horizon, soil-related cracks can be observed to a depth of $67.65 \mathrm{~m}$. This horizon which displays palaeosol features is situated $1.5 \mathrm{~m}$ beneath the top of the Terwagne Limestone. Macroscopically, it is characterised at the base by a $20 \mathrm{~cm}$ thick lightgray limestone with darker fragments or relics of the original limestone, fractures and some sparite zones. Above this, a $10 \mathrm{~cm}$ thick light-gray zone with a semi-brecciated 
appearance, created by numerous cracks, is present. Several generations of cracks and crack fillings can be recognised. Subsequently, a $7 \mathrm{~cm}$ thick horizon with lightgray small $(<1 \mathrm{~mm}-1 \mathrm{~cm})$ fragments in a darker gray matrix forms a glaebule horizon. Around many of the glaebules, circumgranular cracks developed as well as nicely zoned rhombic calcites (Plate II.6). Relics of the host rock consist mainly of peloidal grainstones, with relics of oolites and few calcispheres and ostracods. Locally microsparite occurs in a micritic matrix forming a grumelous texture. This texture can be explained by recrystallisation of a peloidal grainstone to microsparite or it may relate to soil forming processes (Folk, 1965). Under cathodoluminescence, compacted pellets can be distinguished. The brecciated appearance of the middle palaeosol zone $(67.12-67.02 \mathrm{~m})$ is caused by the presence of a complex network of dirty brown microsparite to sparite crystals, which developed around the fragments. A desiccation crack above the brecciated zone is filled with calcite cement. The glaebules float within a complex microsparite to sparite network comparable to that of the brecciated zone.

Despite the compact nature of this lithology five different calcite cement generations can be distinguished. Detailed descriptions are given in table 3. Calcite cement P1 consists of a dirty brown, fine-crystalline sparite cement, which developed around fragments in the grainstone. Locally it has an acicular outline. This cement displays a dull dark brown luminescence to non- luminescence with bright orange-yellow spots. Calcite cement P2 consists of blocky sparite crystals, with a non-luminescent core (Plate II.4 \& 5) around which sometimes several $\mu \mathrm{m}$-thin bright yellow to orange-yellow CL-zones developed. Calcite cement P3, which fills up a desiccation crack in the glaebule horizon, is composed of several phases: (1) a dull brown to nonluminescent phase (see for example Plate II.4 \& 5), (2) a non-luminescent phase with locally $\mu \mathrm{m}$-thin bright-yellow luminescent zones and (3) a zoned dull brown to orangebrown phase. All these phases also occur between the glaebules. Calcite cement P4 consists of blocky sparite crystals, sometimes with irregular contacts and a non-uniform extinction. It is characterised by a dull orange-brown to dark brown luminescence, often with sector zonation and red luminescent spots. It thus resembles the $\mathrm{C} 3$-cement described above. Within some of the larger intergranular pores a paragenetic succession composed of $\mathrm{P} 1, \mathrm{P} 2$ and $\mathrm{P} 4$ can be seen. P5, which crosscuts the former generations, consists mainly of dull orange-brown to yellow-orange luminescent calcite with sector zonation (Plate II.4). The latter two phases only occur in fractures. Notice that the crack-filling cement P3 is crosscut by thin fractures cemented by P4 and P5.

Irregular to cubic pyrite crystals (Py) as well as isolated irregular to hexagonal quartz crystals (Q) preferentially occur along the steep dipping S2-stylolites. The S2stylolites crosscut P3-cements, while P4 locally fills up or crosscuts the S2-stylolites.

\begin{tabular}{|c|c|c|c|}
\hline & general aspect & CL-characteristics/zonations & occurrence \\
\hline P1 & $\begin{array}{l}\text { «dirty» brown coloured fine } \\
\text { crystalline sparite with } \\
\text { sometimes acicular outline }\end{array}$ & $\begin{array}{l}\text { Dull DB to NL with bright } \\
\text { O-Y spots }\end{array}$ & around grainstone allochems \\
\hline P2 & blocky sparite & $\begin{array}{l}\text { NL (with sometimes bright } \mathrm{Y} \text { to OY } \\
\mu \mathrm{m} \text {-thick outer zonations) }\end{array}$ & $\begin{array}{l}\text { interparticular cement in crack-like } \\
\text { features }\end{array}$ \\
\hline P3 & blocky sparite & $\begin{array}{l}\text { complex CL-pattern, locally dull B } \\
\text { to NL,NL with } \mu \text { m-thick bright } Y \\
\text { zonations, dull B to OB zoned calcite }\end{array}$ & $\begin{array}{l}\text { observed as desiccation crack infill, } \\
\text { between glaebules }\end{array}$ \\
\hline S2 & steeply inclined & I & sometimes $100 \mu \mathrm{m}$-thick seams \\
\hline P4 & $\begin{array}{l}\text { blocky sparite, undelous extinction, } \\
\text { irregular crystal contacts }\end{array}$ & $\begin{array}{l}\text { Dull OB to DB with sector zonations } \\
\text { and red spots }\end{array}$ & $\begin{array}{l}\text { in thin fractures crosscutting P1 to P3, } \\
\text { occur all over Terwagne Formation }\end{array}$ \\
\hline P5 & blocky sparite & Dull OB to YO with sector zonations & $\begin{array}{l}\text { in thin fractures crosscutting P1 to P4, } \\
\text { occur all over Terwagne Formation, } \\
\text { crosscuts S2, fills up S2 }\end{array}$ \\
\hline Q & authigenic quartz crystals & $\mathrm{NL}$ & clustered around S1 \& S2 stylolites \\
\hline Py & authigenic pyrite & NL & dull orange-red \\
\hline
\end{tabular}

Table 3. Main characteristics of the most important diagenetic products in the carbonates of the Terwagne Formation. P1 to P5 in paragenetic order. Abbreviations: see table 2. 
With the exception of one sample all $\delta^{18} \mathrm{O}$-values of the soil related samples are situated within a small range varying from $-7.2 \%$ to $-8.6 \%$ PDB. The $\delta^{13} \mathrm{C}$-values vary between $-5.95 \%$ and $-1.03 \%$ PDB (Table 3 and figure 6). The only calcite cement generation that could be separated for analysis consisted of $\mathrm{P} 4$, derived from fractures. Its $\delta^{18} \mathrm{O}$-signature varies from $-16.6 \%$ to $11.1 \%$ PDB while the $\delta^{13} \mathrm{C}$-signature ranges between $0.81 \%$ o to $-0.38 \%$ o PDB.

\section{Interpretation:}

Similar palaeosol features have been described in detail from the Terwagne Formation in eastern Belgium (Maes et al.,1989; Peeters et al., 1992). The glaebules, the brecciated zone and the rhombic microsparite crystals together with the absence of needle crystals and traces of biologic activity are characteristic for an alpha-soil (Wright \& Peeters, 1989; Tucker \& Wright, 1990). The rhombic calcites are comparable to the soilrelated crystals described by Wright and Peeters (1989). The variation in luminescence characteristics of the P1to P3-cements, and their dominant dull to non-luminescent aspect with the exception of $\mu \mathrm{m}$-thick bright yellow features, is typical for cementation in soils. These changes can be explained by the cyclic variation in moisture content and the changes in physico-chemical parameters (saturation degree, Eh-pH, ...). The mutual relationships between the different cements shows that the P1- to P2-cements can be considered to be early diagenetic while P4 and P5 post-date the development of LPS- or S2-stylolites. Additional late diagenetic phases are the development of pyrite and authigenic quartz. Their spatial relationship with the stylolites suggests that the fluid(s) generating these phases preferentially circulated along these rock heterogeneities.

The depleted oxygen isotope values are typical for a mineralogical stabilisation by meteoric fluids associated with soil development. The $\delta^{13} \mathrm{C}$-values are determined by soil gas, the dissolution of host rock carbonates and atmospheric $\mathrm{CO}_{2}$ (Allan \& Matthews, 1982). Its range overlaps the $\delta^{18} \mathrm{O}$-values of the Terwagne host rock limestones, while the $\delta^{13} \mathrm{C}$-values are similar or more depleted (Fig. 6). The isotopic signature of the $\mathrm{P} 4$-calcites can best be explained by fracture fill at high temperature under deep burial conditions or at least the fluids relate to such a deep burial origin. The $\delta^{13} \mathrm{C}$-values are slightly depleted with respect to the Lower Carboniferous marine carbonates, which might again reflect the temperature dependence of the carbon isotopic fractionation.

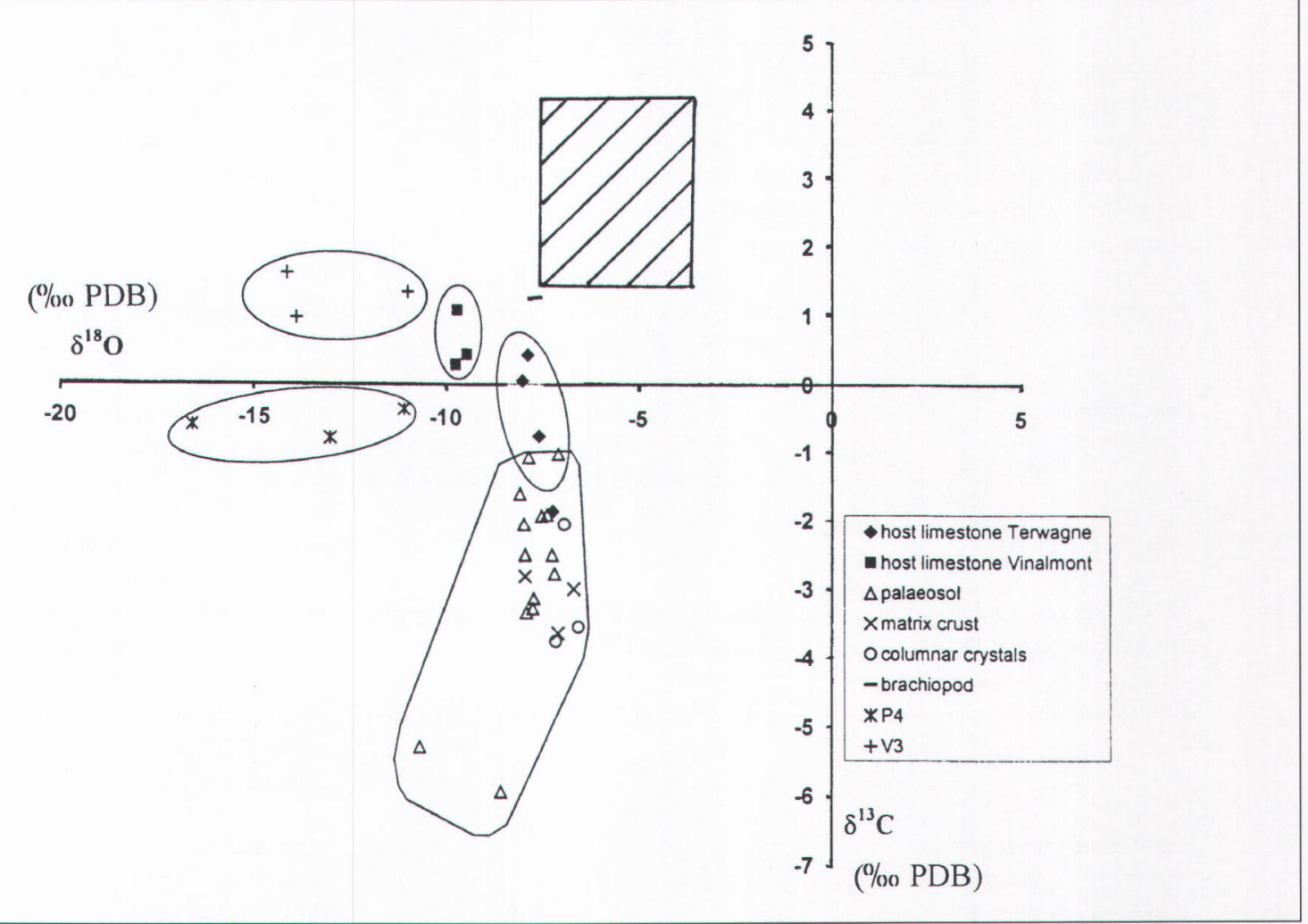

Figure 6. Stable isotope plot of host rock limestone of the Terwagne and Vinalmont Formation with special emphasis for diagenetic products related to the paleosol and subaerial crusts. The hashed area represents the reference area of the marine Lower Carboniferous limestones. 


\subsection{The subaerial crusts $(79.5 \mathrm{~m}$ to $74.6 \mathrm{~m})$}

\section{Description:}

At least two subaerial crusts have been differentiated. The deepest subaerial crust (79.50m-79.38m) gradually passes downwards into the partly dolomitised mudstones with a brecciated character. Here several irregular, rounded lightgray dolomite fragments with cracks are present in a darker gray dolomite matrix. Numerous mm-thin subvertical fractures cut the dolomite. These fractures become less well-defined towards the top of the crust where a thin light-gray calcite horizon occurs. The latter marks the upper surface of the subaerial crust. Above this horizon a cm-large columnar calcite horizon is present which is separated from the calcite horizon by a subhorizontal stylolite. Whether the crust is entirely preserved or not or whether the columnar calcite is genetically linked to the subaerial crust is not inferable.

The upper subaerial crust $(74.83 \mathrm{~m}-74.60 \mathrm{~m})$ is characterised by its brown-gray color and the existence of columnar calcite crystals. At $74.65 \mathrm{~m}$ a red palisade calcite level composed of some long mm-thin columnar crystals with a downward growth direction can be observed. At $74.70 \mathrm{~m}$ a cm-wide brown clay layer is present.

The columnar calcite crystals in both subaerial crusts display similar microscopic features. Crystal diameters vary from $0.16 \mu \mathrm{m}$ to $1.5 \mathrm{~mm}$ and have width:length ratios varying from $1: 5$ to $1: 15$. Most crystals display uniform extinction while on group level a fan-like extinction exists. In the latter case the crystals are similar in size. Straight cleavage twins are very common. Despite the fact that many original textures are obscured due to neomorphism, a competitive crystal growth is deducible. With the exception of the crystal terminations, which are inclusion-poor, many inclusions occur along the columnar crystal axis. It is likely that Fe-oxide/hydroxide inclusions cause the reddish color of the crystals. The individual columnar crystals are mainly non- to dull dark-brown luminescent, with dull yellow-orange to yellow-brown luminescent outer zones, comparable to the P2- and P3-cements described from the palaeosol horizon. The complex spotted CL-pattern in several columnar crystals points to partial recrystallisation. Also dull red-luminescent spots are present which support replacement by dolomite.

Subhorizontal stylolites (S1) contain clay minerals and pyrite (Py). Pyrite also occurs along the rims of columnar crystals and in columnar calcite overgrowths. Several $\mu \mathrm{m}$-thin fractures filled by P5-calcite crosscut S1stylolites, while P3-cements are affected by these stylolites. Authigenic quartz crystals (Q) preferentially occur along S1-stylolites.

The $\delta^{18} \mathrm{O}$-values of the two crusts, including both matrix and columnar calcites, plot within a limited range varying from $-7.9 \%$ to $-6.6 \%$ PDB (Figure 6 and Table 3). Their $\delta^{13} \mathrm{C}$-values vary between $-3.77 \%$ and $-2.06 \%$ o PDB.

\section{Interpretation:}

Whether the columnar phases formed during or after the formation of the subaerial crusts could not be unraveled based on petrographical observations alone. This is mainly due to the severe degree of neomorphism, i.e. microsparitisation. However, the stable oxygen isotope compositions of the columnar calcites are similar to the $\delta^{18} \mathrm{O}$-values of the palaeosol at the top of the Terwagne Limestone, and thus indicative of a meteoric origin. Involvement of soil-derived $\mathrm{CO}_{2}$ is also reflected in the depleted $\delta^{13} \mathrm{C}$-signature, which again overlaps with the carbon isotope signature of the palaeosol. Notice also that the enclosing micrite matrix displays similar stable isotope values and thus likely formed in a similar diagenetic environment. These values are also in line with the stable isotope values recorded in the intra-Dinantian C1-columnar calcites on top of the Grande Dolomie de Namur (compare with Fig. 4). In contrast to the observations made by Muchez et al. (1993), no enrichment in $\delta^{18} \mathrm{O}$ in relation to evaporation has been recognised in the Vinalmont emergence horizons. This might relate to the erosion of the uppermost parts of these horizons, which corroborates with their limited vertical thickness. The light-gray dolomite fragments in the lower crust might correspond to dolocrete nodules or glaebules.

\section{The Vinalmont Limestone Formation (65.0m to $25.1 \mathrm{~m})$}

\section{Description:}

A more varied fauna assemblage characterises the different microfacies that can be distinguished in the Vinalmont Limestone. The main bioclasts are foraminifera, ostracods, brachiopods, bivalves, green algae and crinoids. Also calcispheres occur next to peloids and pellets. In this reconnaissance sedimentological study of this formation up to 7 characteristic microfacies were recognised.

They are:

Microfacies A: oolitic and bioclastic grainstone with a varied fauna.

Microfacies B: bioclastic wacke- to grainstone. The bioclasts consist dominantly of brachiopods and undetermined shell material, crinoids and algal mats. Pellets, peloids, calcispheres and intraclasts are the main allochems.

Microfacies C: bioclastic fenestral packstone. The fenestrae are filled with a blocky sparite cement, which developed upon acicular crystals.

Microfacies D: oncolitic pack- to grainstone with $\mathrm{mm}$ to cm-large oncolites, which developed around reworked algae or shell fragments. A dirty brown acicular cement is present around several allochems.

Microfacies E: oolitic pack- to grainstone. Radial textures are often preserved within the oolites. Other dominant constituents are pellets, lithoclasts composed of pellets and oolites, and some calcispheres. 
Microfacies F: an oolitic grainstone with some $\mathrm{cm}$-large lithoclasts, pellets and peloids, calcispheres and foraminifera. The rims of these fragments are micritised and show 'dirty' brown circumgranular acicular cements. Microfacies G: bioclastic pack- to grainstone with crinoids, foraminifera, undetermined shells, calcispheres and algae.

These limestones are dominantly dull luminescent. The allochems have a similar luminescence as the surrounding cements and thus are difficult to distinguish. They have a dull brown to dull orange-brown luminescence often with bright yellow luminescent spots. These spots locally mark the laminae in the oolites.

Four calcite cements can be distinguished of which detailed descriptions are given in table 4. Calcite cement $\mathrm{V} 1$ is only of local importance and consists of acicular non-luminescent crystals with bright yellow luminescent spots. It is present around some oolites and in some fenestrae. The blocky calcite cement V2 is non-luminescent with some $\mu \mathrm{m}$-thin bright, yellow-orange zonations present in the crystal terminations. It occurs in calcispheres, relics of algae and shell moulds and in fenestrae. Often it forms the first phase of the syntaxial cements, which develop around crinoids. The blocky calcite cement V3 is dull brown to orange-brown luminescent. This cement also occurs is some of the few fractures. The remaining inter- and intraparticle porosities are entirely filled with this cement. Thus V2 and V3 are the dominant cement types. V4 is present in $\mu \mathrm{m}$-thin fractures and consists of a dull to bright orange-yellow to yellow luminescent phase with some darker zones. The Vinalmont Limestone is furthermore characterised by well-developed subhorizontal stylolites (S1). Along the latter, cavities, clay, pyrite (Py) and rarely quartz crystals (Q) occur.
One well-developed non-luminescent brachiopod shell was analysed for its stable isotope composition. Its $\delta^{18} \mathrm{O}$ - and $\delta^{13} \mathrm{C}$-values were $-7.7 \%$ and $+1.2 \%$ PDB respectively. Host rock limestones dominantly composed of marine components plot between $-9.7 \%$ and $-9.45 \%$ PDB for $\delta^{18} \mathrm{O}$ and +0.3 to $+1.1 \%$ o PDB for $\delta^{13} \mathrm{C}$ (Fig. 6). The samples collected containing V3-cements are somewhat more depleted with $\delta^{18} \mathrm{O}$-values between $-14.2 \%$ and $-11.0 \%$ PDB and $\delta^{13} \mathrm{C}$-values between +0.95 and $+1.6 \%$ o PDB (Fig. 6).

\section{Interpretation:}

All these microfacies are indicative of open marine, shallow subtidal depositional environments (Tucker and Wright, 1990). This is especially reflected in the wide variety in fossil species. With regard to the cements, the $\mathrm{V} 1$-calcites are interpreted as marine phreatic in origin. $\mathrm{V} 2$-cements are still early diagenetic in origin but it is unclear whether they are marine or shallow meteoric phreatic in origin. Since no emergence occurred during deposition of this limestone the former interpretation is preferred here. V3- and V4-cements post-date fracturation. The depleted oxygen isotopic signature of the V3-calcites supports a burial origin, with involvement of hot fluids. Whether this also accounts for the last episode of fracture filling is not known. Notice that the Vinalmont Limestones are slightly depleted in oxygen with regard to Lower Carboniferous marine calcite. This is most likely the result of recrystallisation due to interaction with meteoric fluids. This might also explain the limited range in depleted $\delta^{18} \mathrm{O}$-values. Notice that the $\delta^{13} \mathrm{C}$-values of the limestone, the brachiopod shell and the V3-calcite cement are all close to the values reported for Lower Carboniferous marine carbonates. Consequently if recrystallisation occurred the carbon isotopic composition was rock buffered.

\begin{tabular}{|c|c|c|c|}
\hline & general aspect & CL-characteristics/zonations & occurrence \\
\hline V1 & acicular & NL with bright $Y$ spots & interparticular and in fenestrae \\
\hline V2 & blocky sparite & $\begin{array}{l}\text { NL with sometimes } \mu \mathrm{m} \text {-thin bright } \mathrm{Y} \\
\text { to OY outer zonations }\end{array}$ & $\begin{array}{l}\text { dominantly intraparticular within } \\
\text { fenestrae first syntaxial overgrowths } \\
\text { locally interparticular }\end{array}$ \\
\hline V3 & blocky sparite & Dull B to OB & $\begin{array}{l}\text { Fills remaining pores upon V2-syntaxial } \\
\text { cements in fractures }\end{array}$ \\
\hline V4 & equant & $\begin{array}{l}\text { Dull to bright } \mathrm{OY} \text { to } \mathrm{Y} \text { with } \mathrm{B} \text { to } \\
\text { OB zonations }\end{array}$ & few $\mu$ m-thin fracture fill \\
\hline $\mathrm{S} 1$ & subhor. to weakly inclined & 1 & weakly developed \\
\hline Py & authigenic pyrite & NL & dull orange-red \\
\hline Q & authigenic quartz crystals & NL & clustered around S1 \& S2 stylolites \\
\hline
\end{tabular}

Table 4. Main characteristics of the most important diagenetic products in the in the carbonates of the Vinalmont Formation. V1 to V4 in paragenetic order. Abbreviations: see table 2. 


\section{Conclusions}

Lower Carboniferous carbonates of the Namur syncline in the area around Moha have been studied, with special emphasis to the borehole of Vinalmont. This study focussed especially on the interval from the top of the Grande Dolomie de Namur Formation to the top of the Vinalmont Limestone Formation. The dolomites of the Grande Dolomie de Namur Formation are considered to be eogenetic, be it due to reflux of saline to hypersaline fluids or due to seawater circulation adjacent to the development of a mixing zone or both. The stable oxygen isotopic signature of these host rock dolomites $(-13.9 \%$ o to $-13.5 \%$ ), however, does not concur with the proposed dolomitisation models and thus can not help to discriminate between them. The oxygen isotopic signature has clearly been reset by recrystallisation due to interaction with high temperature fluids. The carbon isotopic composition of the dolomites $(-1.68 \%$ o to $+1.50 \%$ PDB $)$ falls roughly in the interval recorded for Lower Carboniferous marine calcite, and thus has been preserved. Columnar calcites fill up many of the cavities within these dolomites, whereby the palaeo-speleothem of Upper Tournaisian/Lower Visean age are characterised by the development of dominantly non-luminescent columnar calcite with growth bands with microsparite intercalations of detrital origin. Their stable isotopic signature supports the meteoric origin of the crystals with the depletion in stable carbon isotopes explained by soil and karst processes $\left(\delta^{18} \mathrm{O}\right.$ - and $\delta^{13} \mathrm{C}$-values of $-6.5 \%$ to $-10.3 \%$ o PDB and $-2.47 \%$ to $-4.79 \%$ respectively). In the Vinalmont borehole the 'Encrinite de Flémalle' and the 'Limestone of Avins' are missing. This is either explained by non-deposition or erosion in relation to the just cited karstification and is related to the northern position of the studied region with respect to the Brabant Massif palaeohigh. It is likely that during this karstification event the intercalated limestones in the dolomite succession have been reset. Interaction by meteoric water containing soil-derived $\mathrm{CO}_{2}$ explains the depleted $\delta^{18} \mathrm{O}$ - and $\delta^{13} \mathrm{C}$ values (respectively varying between $-7.77 \%$ and $12.60 \%$ PDB and $-3.04 \%$ and $-2.09 \%$ PDB). Also in the overlying Terwagne Formation several features point towards restricted sedimentation conditions with episodic emergence as testified by the development of palaeosols and subaerial crusts. The stable isotope compositions of these horizons support soil-related processes. An evolution towards more open marine subtidal sedimentation conditions in the Vinalmont Limestones (dominantly pack- to grainstones) was deduced from varied fauna assemblage and sedimentary characteristics. The original marine oxygen isotope signature has also been reset due to interaction with meteoric fluid(s) (-9.7 and $-9.4 \%$ oPDB) but their $\delta^{13} \mathrm{C}(+0.27$ to $+1.07 \%$ o still reflects a marine Lower Carboniferous signature.
The study of late diagenetic features are constrained by the development of bed-parallel and steeply inclined stylolites. The former is compactional in origin, while the latter relate to layer parallel shortening during tectonic deformation. They thus are Variscan in origin. Late diagenetic zebra-dolomite formation has been observed in the Grande Dolomie de Namur Formation. This dolomite is interpreted to have been formed out of hot (mean Th of $115^{\circ} \mathrm{C} ; \delta^{18} \mathrm{O}$ of $-9.1 \%$ to $-9.4 \%$ ) suprahydrostatic fluids circulating along faults. The high temperature nature of these dolomites might also be reflected in the depleted $\delta^{13} \mathrm{C}$-signature (-3.09\% and $-2.08 \%$ o PDB), which may relate to temperature dependent carbon fractionation or involvement of depleted carbon derived from decarboxylation processes. Interesting feature here is that the isotopic signature of the host rock dolomite seems to be unaffected by zebra dolomite formation with the exception of small alteration zones which developed around the zebra dolomites. The development of mono-crystalline non-luminescent columnar calcites in these dolomites, filling up large cavities is a second important late diagenetic process. They are interpreted to be the product of hydrothermal karstification, based on the high homogenisation temperatures reported by Nielsen et al. (2001) for equivalent nearby lithologies and the depleted $\delta^{18} \mathrm{O}$-values varying between -16.2 to $-16.7 \%$ PDB. $\delta^{13} \mathrm{C}$ values range from -1.17 to $0.07 \%$ PDB. It are possibly the latter fluids which caused recrystallisation of the host rock dolomites. Furthermore several fracturation events followed by cementation have been recognised of which the latter typically are characterised by bright yellow luminescent calcite. They are thought to relate to thermal sulphate reduction and thus could be time equivalent with the crystallisation of late diagenetic pyrite along stylolite seams. The pyrites are often spatially associated with authigenic quartz.

\section{Acknowledgements.}

We thank H. Nijs for making the thin-sections. The stable isotope analysis were carried out in the laboratory for stable isotopes (Vrije Universiteit Brussel, Prof. E. Keppens).

\section{References}

ALLAN, J.R. \& MATTHEWS, R.K., 1982. Isotope signatures associated with early meteoric diagenesis. Sedimentology, 29: 797-817.

BOTTINGA, Y., 1968. Calculation of fractionation factors for carbon and oxygen exchange in the system calcite - carbon dioxide - water. Journ. Phys. Chemistry, 72: 800-808. 
BRUCKSCHEN, P.; OESMANN, S. \& VEIZER, J., 1999. Isotope stratigraphy of the European Carboniferous: proxy signals for ocean chemistry, climate and tectonics. Chemical Geology, 161: 127-163.

BRUCKSCHEN, P. \& VEIZER, J., 1997. Oxygen and carbon isotopic composition of Dinantian brachiopods: Paleoenvironmental implications for the Lower Carboniferous of wetern Europe. Palaeogeogr. Palaeoclim., Palaeoecol., 132: 243-264.

DAMIAEN, G., 1956. La sédimentation depuisla transgression dévonienne jusqu'au Viséen dans la région de Huccorgne (flanc nord du synclinal de Namur). Annales de la Société géologique de Belgique, 79: B364-B382.

DICKSON, J.A.D., 1966. Carbonate identification and genesis as revealed by staining. Journal of Sedimentary Petrology, 36: 491-505.

EMRICH, K.; EHHALT, D.H. \& VOGEL, J.C., 1970. Carbon isotope fractionation during the precipitation of calcium carbonate. Earth and Planetary Science Letters, 8: 363-371.

FOLK, R.L., 1965. Some aspects of recrystallization in ancient limestones. In: Dolomitisation and limestone diagenesis (Eds. Pray, L.C., Murray, R.C.), Spec. Publ. Soc. Econ. Paleont. Mineral., 13: 14-48.

FONTBOTÉ, L. 1993. Self-organisation fabrics in carbonate-hosted ore deposits: the example of diagenetic crystallisation rhythmites (DCRs). In: P. Fenoll HachAli, J. Torres-Ruiz and F. Gervilla (eds). Current research in geology applied to ore deposits. Proceedings of the Second Biennial SGA Meeting, Granada, Spain. University of Granada, Granada: 11-14.

FONTBOTÉ, L. \& GORZAWSKI, H. 1990. Genesis of the Mississippi Valley-Type $\mathrm{Zn}-\mathrm{Pb}$ Deposit of San Vincente, Central Peru: Geologic and Isotopic ( $\mathrm{Sr}, \mathrm{O}, \mathrm{C}$, $\mathrm{Pb}$ ) evidence. Economic Geology, 85: 1402-1437.

GILES, M.R. \& DE BOER, R.B., 1989. Secondary porosity: Creation enhanced porosities in the subsurface from the dissolution of carbonate cements as a result of cooling formation waters. Mar. Petr. Geol., 7: 378-397.

Gregg, J.M. and Sibley, D.F., 1984. Epigenetic dolomitization and the origin of xenotopic dolomite texture, Journal of Sedimentary Petrology, 54: 908-931.

GROESSENS, E., 1985. De steen van Vinalmont. In: Technisch verslag 163 van de werkgroep van het Technisch Komitee Steen en Marmer, bijlage 2. WTCB, 11pp.
HANCE, L. \& GROESSENS, E., 1990. C.B.R. rapport sur la géologie du Fond de Roua à Vinalmont. C.B.R. rapport, $6 \mathrm{pp}$.

HANCE, L.; POTY, E. \& DEVUYST, F.X., 2001. Sequence stratigraphy of the Belgian Dinantian, Geologica Belgica, in press.

HELSEN, S. \& KÖNIGSHOF, 1994. Conodont thermal alteration patterns in Palaeozoic rocks from Belgium, northern France and western Germany. Geological Magazine, 131: 369-386.

HEIJLEN, W.; MUCHEZ, Ph.; BANKS, D. \& NIELSEN, P., 2000. Origin and geochemical evolution of synsedimentary, syn- and post-tectonic high-salinity fluids at the Variscan thrust front in Belgium. Journal of Geochemical Exploration, 69-70: 149-152.

HUDLESTON, P.J. \& HOLST-TIMOTHY, B., 1984. Strain analysis and fold shape in a limestone layer and implications for layer rheology. Tectonophysics, 106: 321347.

KENDALL, A.C., 1985. Radiaxial fibrous calcite: A reappraisal. In: Carbonate Cements, SEPM Special Publication (Eds. Schneidermann, N. \& Harris, P.M.), Spec. Publ. Soc. Econ. Paleont. Mineral., 36: 59-77.

KUPECZ, J.A.; MONTANEZ, I.P. \& GAO, G., 1993. Recrystallisation of dolomite with time. In: Carbonate microfabrics (Eds.: Rezak, R and Lavoie, D.L.), SpringerVerlag, Berlin: 187-194.

LOHMANN, K.C., 1987. Geochemical patterns of meteoric diagenetic systems and their application to studies of paleokarst. In: Paleokarst (Eds.: James, N.P. \& Choquette, P.W.), Springer-Verlag, Berlin: 58-80.

MACHEL, H.G., 2000. Application of cathodoluminescence to carbonate diagenesis. In: Cathodoluminescence in geosciences. Ed.: Pagel, M.; Barbin, V.; Blanc, P. \& Ohnenstetter, D., Springer-Verlag, Berlin: 271-302.

MACHEL, H.G. \& BURTON, E.A., 1994. Golden Grove Dolomite, Barbados: origin from modified seawater. Journal of Sedimentary Research, A64: 741-751.

MACHEL, H.G.; KROUSE, H.R. \& SASSEN, R., 1995. Products and distinguishing criteria of bacterial and thermochemical sulfate reduction. Appl. Geochem., 10: 373-389. 
MAES, K.; PEETERS, C.; MUCHEZ, Ph.; SWENNEN, R. \& VIAENE, W., 1988. The occurrence of paleosols in the Lower Visean of the Walhorn section (Vesder Basin, E-Belgium). Annales de la Société géologique de Belgique, 112: 69-77.

MUCHEZ, Ph.; PEETERS, C.; KEPPENS, E. \& VIAENE, W., 1993. Stable isotopic composition of paleosols in the Lower Viséan of eastern Belgium: evidence of evaporation and soil-gas $\mathrm{CO}_{2}$. Chemical Geology, 106: 389-396.

MUCHEZ, Ph.; PEETERS, C.; VIAENE, W. \& KEPPENS, E., 1992. Stable isotope composition of an evaporite dissolution breccia in the Lower Viséan limestones of SE Belgium, Chemical Geology, 102: 119-127.

MUCHEZ, Ph.; SINTUBIN, M. \& SWENNEN, R., 2000. Origin and migration pattern of palaeofluids during orogeny: discussion on the Variscides of Belgium and northern France. Journal of Geochemical Exploration, 9-70: 47-51.

MUCHEZ, Ph.; SLOBODNIK, M.; VIAENE, W. \& KEPPENS, E., 1995. Geochemical constraints on the origin and migration of palaeofluids at the northern margin of the Variscan foreland, southern Belgium. Sedimentary Geology, 96: 191-200.

MUCHEZ, Ph. \& VIAENE, W., 1984. Dolomitisation caused by water circulation near the mixing zone: an example from the Lower Viséan of the Campine Basin (northern Belgium). In: Dolomites - A volume in honour of Dolomieu (Eds: Purser, B.H., Tucker, M. \& Zenger, D.H.) Spec. Publ. Int. Assoc. Sedimentologists, 21: 155-166.

NIELSEN, P., 1996. Origin and diagenetic reactivity of dolomites from the Dinantian South-East of the BrabantWales Massif. Unpubl. Ph. D.-thesis V.U. Brussels, $159 \mathrm{pp}$.

NIELSEN, P.; SWENNEN, R. \& KEPPENS, E., 1994. Multiple-step recrystallisation within massive ancient dolomite units: an example from the Dinantian of Belgium, Sedimentology, 41: 567-584.

NIELSEN, P.; SWENNEN, R.; MUCHEZ, Ph. \& KEPPENS, E., 1998. Origin of Zebra dolomites south of the Brabant-Wales Massif, Belgium. Sedimentology, 45: 666-679.

NIELSEN, P.; SWENNEN, R.; GROESSENS, E.; MUCHEZ, Ph.; HEIJLEN, W.; FALLICK, A.E.; KEPPENS, E \& WEIS, D., 2001. Columnar calcites at the boundary between Upper Tournaisian dolomites and limestones (Belgium): multiple origins for apparently similar features. Sedimentology (under reviewing).
PEETERS, C.; SWENNEN, R.; NIELSEN, P. \& MUCHEZ, Ph., 1992. Sedimentology and diagenesis of the Visean carbonates in the Vesder area (Verviers synclinorium : E-Belgium). Zbl. Geol. Paläont.: 519-547.

SMITH, T.M. \& DOROBEK, S.L., 1993. Alteration of early-formed dolomite during shallow to deep burial: Mississippian Mission Canyon Formation, central to southwestern Montana. Geol. Soc. Am. Bull., 105, 1389-1399.

STRASSER, A., 1986. Ooids in Purbeck limestones (lowermost Cretaceous) of the Swiss and French Jura, Sedimentology, 33: 711-727.

SWENNEN, R., 1984. Stratigrafie, sedimentologie en relaties tussen lithochemie en $\mathrm{Pb}-\mathrm{Zn}$ mineralisaties van het Dinantiaan in het synclinorium van Verviers. Unpublished Ph.D.-thesis, K.U. Leuven, 272pp.

SWENNEN, R.; VIAENE, W. \& CORNELISSEN, C., 1990. Petrography and geochemistry of the Belle Roche breccia (lower Visean, Belgium): evidence for brecciation by evaporite dissolution. Sedimentology, 37: 859-878.

TEICHMÜLLER, M. \& TEICHMÜLLER, R., 1979. Ein Inkohlungsprofil entlang der linksrheinischen Geotraverse von Schleiden nach Aachen und die Inkohlung in der Nord-Süd-Zone der Eifel. Fortschritte in der Geologie von Rheinland und Westfalen, 27: 201-76.

TUCKER, M. \& WRIGHT, V.P., 1990. Carbonate sedimentology. Blackwell Scientific Publications, Oxford, $482 \mathrm{p}$.

WALKDEN, G.M. \& WILLIAMS, D.O, 1991. The diagenesis of the late Dinantian Derbyshire-East Midland carbonate shelf, central England. Sedimentology, 38: 643-670.

VAN GEET M.; SWENNEN R.; DURMISHI C.; ROURE F. \& MUCHEZ, Ph., 2001. Diagenesis of Cretaceous to Eocene carbonate reservoirs in the Ionian fold and thrust belt (Albania): the relation between tectonism and fluid flow. Sedimentology (under reviewing).

WRIGHT, V.P. \& PEETERS, C., 1989. Origin of some Early Carboniferous calcrete fabrics revealed by cathodoluminescence: implications for interpreting the sites of calcrete formation. Sedimentary Geology, 65: 345-353.

Manuscript received on 18.1.2001 and accepted for publication on 14.9.2001 


\begin{tabular}{|c|c|c|c|}
\hline & $\operatorname{depth}(m)$ & $\delta^{18} \mathrm{O}$ & $\delta^{13} \mathrm{O}$ \\
\hline host rock dolomite & 112.80 & -13.90 & 0.87 \\
\hline host rock dolomite & 122.30 & -13.70 & 1.50 \\
\hline host rock dolomite & 124.70 & -13.50 & -1.68 \\
\hline hostrock limestone & 89.65 & -7.77 & -2.31 \\
\hline hostrock limestone & 91.85 & -7.80 & -3.04 \\
\hline hostrock limestone & 97.50 & -7.94 & -2.09 \\
\hline hostrock limestone & 110.95 & -12.60 & -2.26 \\
\hline hostrock limestone & 120.50 & -8.53 & -0.91 \\
\hline altered zone & 122.30 & -10.30 & -1.24 \\
\hline altered zone & 122.30 & -9.70 & -1.79 \\
\hline zebra dolomite: light grey & 120.70 & -9.10 & -2.88 \\
\hline zebra dolomite: light grey & 120.70 & -9.40 & -3.04 \\
\hline zebra dolomite: light grey & 129.20 & -9.30 & -2.33 \\
\hline zebra dolomite: white & 120.70 & -9.20 & -3.04 \\
\hline zebra dolomite: white & 120.70 & -9.20 & -3.06 \\
\hline zebra dolomite: white & 120.70 & -9.40 & -3.09 \\
\hline zebra dolomite: white & 122.30 & -9.20 & -2.47 \\
\hline zebra dolomite: white & 129.20 & -9.20 & -2.30 \\
\hline zebra dolomite: white & 129.20 & -9.10 & -2.08 \\
\hline microsparite & 89.60 & -7.71 & -3.13 \\
\hline microsparite & 89.65 & -7.77 & -2.31 \\
\hline microsparite & 89.65 & -7.71 & -3.37 \\
\hline microsparite & 91.90 & -7.72 & -2.47 \\
\hline microsparite & 91.90 & -7.57 & -3.81 \\
\hline microsparite & 99.10 & -7.91 & -3.49 \\
\hline microsparite & 108.20 & -7.94 & -3.46 \\
\hline microsparite & 109.10 & -11.62 & -2.63 \\
\hline microsparite & 117.30 & -6.51 & -2.84 \\
\hline microsparite & 117.30 & -11.03 & -2.98 \\
\hline columnar calcite 1 & 89.60 & -7.81 & -2.64 \\
\hline columnar calcite 1 & 89.60 & -10.32 & -3.72 \\
\hline columnar calcite 1 & 89.60 & -7.14 & -2.90 \\
\hline columnar calcite 1 & 89.65 & -7.39 & -2.47 \\
\hline columnar calcite 1 & 89.65 & -9.28 & -3.80 \\
\hline columnar calcite 1 & 89.65 & -7.36 & -3.72 \\
\hline columnar calcite 1 & $89.65 b$ & -7.61 & -3.60 \\
\hline columnar calcite 1 & $89.65 b$ & -9.01 & -3.55 \\
\hline columnar calcite 1 & 91.90 & -6.68 & -3.45 \\
\hline columnar calcite 1 & 99.10 & -6.49 & -3.06 \\
\hline columnar calcite 1 & 108.20 & -7.03 & -2.80 \\
\hline columnar calcite 1 & 108.20 & -7.32 & -2.98 \\
\hline columnar calcite 1 & 109.10 & -9.37 & -2.78 \\
\hline columnar calcite 1 & 109.10 & -9.54 & -3.07 \\
\hline columnar calcite 1 & 109.60 & -7.47 & -3.69 \\
\hline columnar calcite 1 & 113.00 & -8.75 & -4.39 \\
\hline
\end{tabular}

Annex 1a. Vinalmont borehole: stable isotopes analytical data. 


\begin{tabular}{|c|c|c|c|}
\hline & $\operatorname{depth}(m)$ & $\delta^{18} \mathrm{O}$ & $\delta^{13} \mathrm{O}$ \\
\hline columnar calcite 1 & 113.70 & -7.29 & -4.79 \\
\hline columnar calcite 1 & 117.30 & -7.91 & -2.97 \\
\hline columnar calcite 2 & 91.90 & -16.67 & -1.05 \\
\hline columnar calcite 2 & 108.20 & -16.23 & -1.17 \\
\hline columnar calcite 2 & 113.00 & -16.69 & -1.11 \\
\hline columnar calcite 2 & 113.00 & -16.29 & 0.07 \\
\hline host rock limestone Vinalmont & 27.05 & -9.45 & 0.43 \\
\hline host rock limestone Vinalmont & 29.70 & -9.74 & 0.27 \\
\hline host rock limestone Vinalmont & 38.10 & -9.70 & 1.07 \\
\hline host rock limestone Terwagne & 67.70 & -7.56 & -0.77 \\
\hline host rock limestone Terwagne & 70.05 & -7.99 & 0.05 \\
\hline host rock limestone Terwagne & 86.80 & -7.85 & 0.42 \\
\hline host rock limestone Terwagne & & & \\
\hline with pedogenetic features & 67.35 & -7.20 & -1.87 \\
\hline paleosol & 67.03 & -7.49 & -1.94 \\
\hline paleosol & 67.03 & -8.05 & -1.62 \\
\hline paleosol & 67.05 & -7.92 & -2.51 \\
\hline paleosol & 67.05 & -7.94 & -2.06 \\
\hline paleosol & 67.05 & -7.22 & -2.51 \\
\hline paleosol & 67.05 & -8.55 & -5.95 \\
\hline paleosol & 67.11 & -7.82 & -1.08 \\
\hline paleosol & 67.12 & -7.35 & -1.92 \\
\hline paleosol paleosol & 67.13 & -10.68 & -5.31 \\
\hline paleosol & 67.15 & -7.88 & -3.35 \\
\hline paleosol & 67.20 & -7.70 & -3.14 \\
\hline paleosol & 67.20 & -7.16 & -2.78 \\
\hline paleosol & 67.20 & -7.06 & -1.03 \\
\hline paleosol & 67.30 & -7.73 & -3.29 \\
\hline matrix crust & 74.65 & -7.92 & -2.82 \\
\hline matrix crust & 74.70 & -7.07 & -3.65 \\
\hline matrix crust & 79.32 & -6.67 & -3.00 \\
\hline columnar crystals & 74.65 & -6.90 & -2.06 \\
\hline columnar crystals & 74.70 & -7.13 & -3.77 \\
\hline columnar crystals & 79.32 & -6.55 & -3.56 \\
\hline brachiopod & 49.70 & -7.68 & 1.25 \\
\hline $\mathrm{p} 4$ & 67.18 & -13.02 & -0.81 \\
\hline $\mathrm{p} 4$ & 67.20 & -11.09 & -0.38 \\
\hline $\mathrm{p} 4$ & 67.32 & -16.63 & -0.62 \\
\hline V3 & 29.50 & -13.90 & 0.95 \\
\hline V3 & 49.65 & -11.00 & 1.33 \\
\hline V3 & 55.55 & -14.15 & 1.60 \\
\hline
\end{tabular}

Annex 1b. Vinalmont borehole: stable isotopes analytical data. 


\section{Plate 1}

1) Cathodoluminescence photomicrograph of the outer part of white "bands" of zebra dolomite with dull orange-red spotted luminescent crystal core (a) and dull orange-red to brown luminescent outer zones (b). The outermost zone (arrow) is dull brown luminescent. Scale $=165 \mu \mathrm{m}$ (Vinalmont borehole: $127.4 \mathrm{~m}$ ).

2) Transmitted light and cathodoluminescence photomicrograph of the outer part of white "bands" of zebra dolomite with dull orange-red to brown luminescent outer zones, jigsaw-dislocations (arrows) and an outermost dull brown luminescent zone. Scale $=165 \mu \mathrm{m}$ (Vinalmont borehole: $129.2 \mathrm{~m}$ ).

3) Cathodoluminescence photomicrograph of non-crinoidal host rock dolomite with idiotopic-S texture. The core of the dolomite rhomb is purple luminescent with blotchy textures. A dull red luminescent outer zone can be seen. Between the dolomite crystals blocky C2-calcite cement occurs (see arrows). Scale $=165 \mu \mathrm{m}$ (Vinalmont borehole: $112.7 \mathrm{~m})$.

4) Cathodoluminescence photomicrograph of crinoidal host rock dolomite with idiotopic-S to xenotopic-S texture. Within the central core, dull yellow-orange to orange-brown C3-calcite with sector zonation occurs (see arrows). The bright yellow luminescent phases with irregular outline correspond to C6-calcite. Scale $=165 \mu \mathrm{m}$ (Vinalmont borehole: $124.7 \mathrm{~m})$.

5) Macroscopic view of cavity filled by several growth bands of columnar calcite developing perpendicular to the cavity walls. Arrow indicates top of the sample (Vinalmont borehole: 108.2m).

6) Transmitted light photomicrograph under crossed polarisers with different growth bands of columnar calcite separated by detrital silt. This texture is typical for speleothems. Scale $=200 \mu \mathrm{m}$. (Vinalmont borehole $116.8 \mathrm{~m}$ ). 

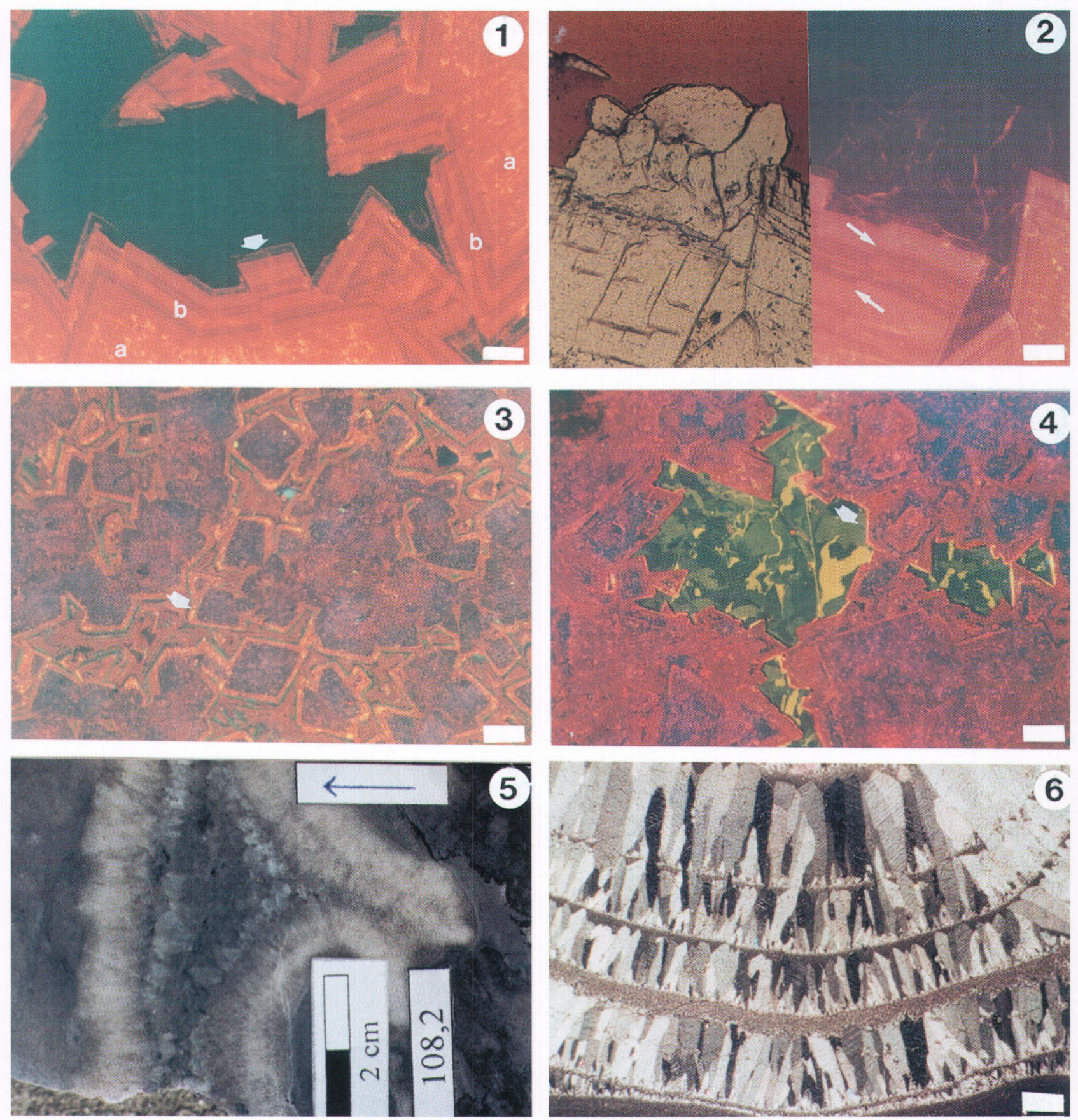


\section{Plate 2}

1) Transmitted light photomicrograph under crossed polarisers of a detail of columnar calcite with detritals filling up the micro-topography (indicated by arrows) between well-developed protruding crystal terminations. Scale $=260 \mu \mathrm{m}$ (Vinalmont borehole: $116.8 \mathrm{~m}$ ).

2) Cathodoluminescence photomicrograph of non-luminescent P1 columnar calcite with yellow-orange luminescent P2 overgrowth phases. The non-luminescent phases in the upper left side of the picture correspond to authigenic quartz crystals (AQ). Scale $=165 \mu \mathrm{m}$ (Vinalmont borehole: $89.65 \mathrm{~m}$ ).

3) Cathodoluminescence photomicrograph of non-luminescent P1 columnar calcite with yellow-orange luminescent P2-overgrowth phases. Notice the presence of pyrite (PY) at the contact of both calcite phases as well as the small fracture in P1 which is filled by P2-calcite (arrows). Scale $=165 \mu \mathrm{m}$ (Vinalmont borehole: $113.7 \mathrm{~m}$ ).

4) Cathodoluminescence photomicrograph of fracture consisting of non-luminescent P2-calcite (P2) bordering the vertical fracture and dull brown-luminescent P3-calcite (P3) in the center. The latter are crosscut by a horizontal yellow-orange luminescent P5-calcite. Scale $=165 \mu \mathrm{m}$ (Vinalmont borehole: $67.25 \mathrm{~m})$.

5) Cathodoluminescence photomicrograph of palaeosol with non-luminescent P2-calcite bordering a cavity, followed by dull brown to orange-brown zoned P3 in the center. The vertical yellow luminescent fracture corresponds to P5-calcite. Scale $=165 \mu \mathrm{m}$ (Vinalmont borehole: $67.10 \mathrm{~m})$.

6) Cathodoluminescence photomicrograph of palaeosol with yellow luminescent nicely zoned rhombic calcites in limestone matrix. Scale $=165 \mu \mathrm{m}$ (Vinalmont borehole: $67.10 \mathrm{~m}$ ). 

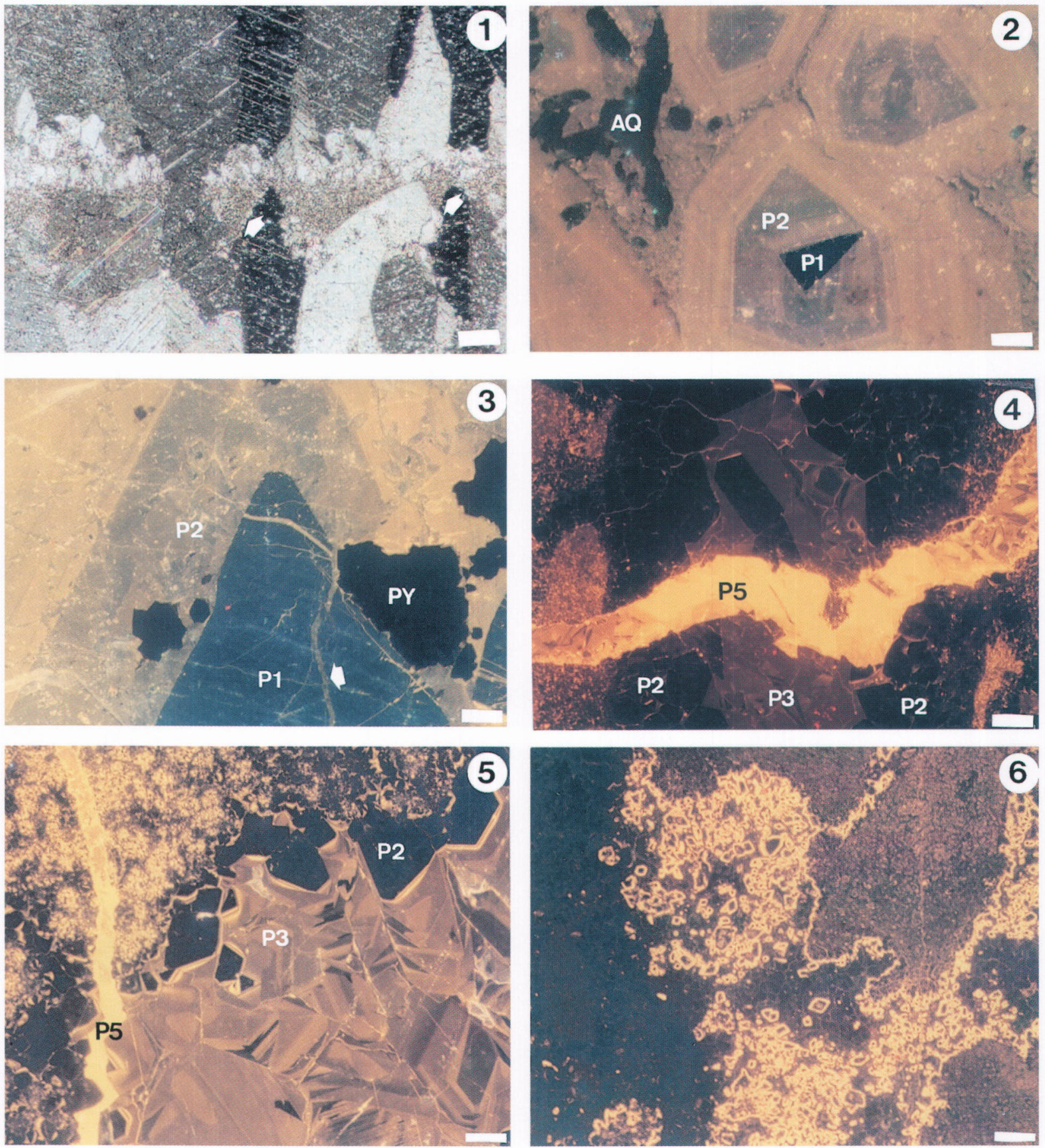